\title{
IMPLEMENTASI KEBIJAKAN PELIMPAHAN URUSAN PEMERINTAHAN LINGKUP KEMENTERIAN DALAM NEGERI
}

\section{POLICY IMPLEMENTATION OF GOVERNMENT AFFAIRS DEVOLUTION SCOPE OF THE MINISTRY OF HOME AFFAIRS}

\author{
Abdul Halik \\ Pusat Penelitian Pemerintahan Umum dan Kependudukan \\ Badan Penelitian dan Pengembangan (BPP) Kementrian Dalam Negeri \\ Jl. Kramat Raya No. 132 - Senen, Jakarta \\ No. Telp./Faks : +62 213140454 ; +62 213101955 \\ E-mail: liknph@yahoo.com \\ Dikirim: 20 Februari 2015 Direvisi: 24 April 2015 Disetujui: 18 Mei 2015
}

\begin{abstract}
Abstrak
Kebijakan dekonsentrasi diselenggarakan karena tidak semua wewenang/urusan pemerintahan dapat dilakukan dengan menggunakan asas desentralisasi. Maksud dari kebijakan itu adalah untuk mensinergikan hubungan pusat dan daerah. Namun, dalam kenyataan tidak semua pelaksanaan kegiatan kebijakan tersebut dapat menghasilkan keluaran yang sesuai dengan rencana dan tujuan kebijakan, termasuk yang dilaksanakan oleh Kementerian Dalam Negeri. Kondisi seperti ini terjadi antara lain karena proses implementasi kebijakan tersebut belum berjalan dengan baik. Kajian ini menggunakan metode naturalistic atau kualitatif dengan eksplanasi yang besifat deskriptif. Tujuan kajian ini adalah untuk mengetahui proses implementasi kebijakan, mengidentifikasi faktor-faktor yang berpengaruh, serta hasil dari implementasi kebijakan pelimpahan urusan pemerintahan melalui mekanisme dekonsentrasi lingkup Kementerian Dalam Negeri di Provinsi Jawa Barat. Hasil kajian ini menunjukkan bahwa secara umum hasil dari implementasi kebijakan dekonsentrasi di Provinsi Jawa Barat relatif sesuai dengan tujuan-tujuan dari pelaksanaan kebijakan dekonsentrasi. Demikian halnya keluaran dari pelaksanaan kegiatan program dekonsentrasi mencapai target sebagaimana yang telah ditetapkan sebelumnya. Walaupun demikian, masih terdapat berbagai kekurangan di dalam proses pelaksanaannya. Kata Kunci: Dekonsentrasi, kesinergian, penganggaran.
\end{abstract}

\begin{abstract}
Deconcentration policies held because not all authority/government affairs can be done by using the principle of decentralization. The intent of this policy is to synergize the central and local relations. However, in reality not all of the activities of these policies can produce output in accordance with the plans and policy objectives, including those carried out by the Ministry of the Interior. Such conditions occur because of the policy implementation process has not been going well. This study uses naturalistic methods or qualitative descriptive explanation besifat. The purpose of this study is to investigate the process of policy implementation, identify the factors that influence, as well as the results of policy implementation devolution of government affairs deconcentration scope of the Ministry of the Interior in the province of West Java. The results of this study indicate that in general the result of the implementation of deconcentration policy in West Java province is relatively accordance with the objectives of the implementation of deconcentration policy. Similarly, the output of the implementation of deconcentration program targets as predetermined. Nevertheless, there are still many shortcomings in the implementation process.
\end{abstract}

Keywords: Deconcentration, synergy, budgeting.

\section{PENDAHULUAN}

Proses penyelenggaraan pemerintahan menjadi salah satu tolok ukur demokrasi. Proses itu sendiri sangat terkait dengan sistem pemerintahan yang dikembangkan oleh suatu negara. Salah satu sistem pemerintahan yang banyak dianut negara adalah sistem desentralisasi dengan otonomi daerah yang luas. Dalam banyak hal, sistem tersebut dipandang efektif karena secara formal, sistem itu menjanjikan pemerintahan yang lebih dekat dengan rakyat dan sekaligus dapat memberdayakan daerah (empowering).

Di Indonesia, paradigma baru penyelenggaraan pemerintahan daerah dengan sistem otonomi daerah yang luas didasarkan pada Undangundang Nomor 32 Tahun 2004 tentang Pemerintahan Daerah. Lahirnya UU ini dapat diangggap sebagai salah satu konsekuensi positif dari proses reformasi sejak krisis ekonomi terjadi, mengisyaratkan telah terjadinya pergeseran paradigma dari sistem pemerintahan yang sentralistik ke sistem pemerintahan yang desentralistik. Dalam sistem yang 
desentralistik itu, prinsip yang dianut adalah otonomi daerah yang luas, namun pelaksanaannya harus didasarkan pada prinsip demokrasi, peran serta masyarakat, pemerataan dan keadilan, serta memperhatikan potensi dan keanekaragaman daerah.

Dalam sistem pemerintahan di Indonesia, Negara Kesatuan Republik Indonesia (NKRI) dibagi atas daerah-daerah provinsi, dan daerah provinsi itu dibagi atas kabupaten dan kota, yang tiap-tiap provinsi, kabupaten, dan kota itu mempunyai pemerintahan daerah (local government) (Perubahan Kedua UUD 1945, Pasal 18, Ayat 1). Eksistensi pemerintahan daerah tersebut memang selalu menarik dan relevan untuk dikaji, terutama jika dikaitkan dengan kebutuhan efektivitas sebuah pemerintahan. Setiap negara dengan wilayah yang luas seperti Indonesia, membutuhkan suatu sistem pemerintahan yang efektif. Selain itu, sistem itu diperlukan tidak saja sebagai instrumen untuk melaksanakan program pemerintah di berbagai daerah negeri yang bersangkutan, tetapi juga - dan itu mungkin lebih penting-sebagai instrumen bagi masyarakat setempat agar dapat berperan serta dalam, dan menentukan prioritas untuk pembangunan daerahnya sendiri (Devas, et al., 2008).

Sesuai dengan UU No. 32 Tahun 2004 tentang Pemerintahan Daerah, dalam menyelenggarakan pemerintahan di atas, pemerintah menggunakan asas desentralisasi, tugas pembantuan, dan dekonsentrasi (Pasal 20, Ayat 2). Artinya, pemerintahan daerah provinsi, daerah kabupaten, dan kota mengatur dan mengurus sendiri urusan pemerintahan menurut asas otonomi (desentralisasi), tugas pembantuan (medebewind), dan dekonsentrasi. Hal ini berarti bahwa Indonesia telah menjatuhkan pilihannya pada sistem pemerintahan daerah yang didasarkan pada decentralization atau local autonomy approach.

Memang, desentralisasi merupakan sebuah gelombang yang hampir pasti tidak bisa lagi dihindari oleh kebanyakan negara. Argumen pokoknya adalah, pemerintahan daerah merupakan suatu institusi yang telah menjadi fenomena umum dalam pemerintahan modern. Selain itu, takkala gelombang demokratisasi mengencang, maka hampir dipastikan akan diikuti dengan mengencangnya gelombang desentralisasi. Dua gelombang ini merupakan hal yang tidak terpisahkan. Demokrasi bermaksud "menyerahkan" pemerintahan kepada rakyat, dan desentralisasi bertujuan untuk “mendekatkan" pemerintahan kepada rakyat. Menurut Iglesias (2007), hal itu hanya bisa terjadi apabila desentralisasi diterapkan pada tataran political decentralization/devolution yang melahirkan daerah-daerah otonom dan administrative decentralization yang melahirkan wilayah-wilayah administratif dengan menggunakan asas dekonsentrasi. Dalam konteks ini, maka tujuan pembentukan dan sifat eksistensi pemerintahan daerah paling tidak mempunyai 2 (dua) segi, yaitu secara politis ataupun secara administratif. Kedua hal tersebut merupakan shifting yang sangat substansial ke arah penerapan asas desentralisasi yang lebih tepat.

Dalam praktik penyelenggaraannya, dekonsentrasi merupakan salah satu jenis desentralisasi (Surianingrat, 2000). Di Indonesia, dekonsentrasi dipahami sebagai pelimpahan wewenang pemerintahan oleh pemerintah (pusat) kepada Gubernur sebagai wakil pemerintah (pusat) dan/atau kepada instansi vertikal di wilayah tertentu. Gubernur karena jabatannya, berkedudukan juga sebagai wakil pemerintah (pusat) di wilayah provinsi yang bersangkutan, dan dalam kedudukannya tersebut, berarti Gubernur bertanggung jawab kepada Presiden. Adapun tugas dan wewenang Gubernur (dan perangkatnya) dalam kedudukannya sebagai wakil pemerintah (pusat) adalah sebagai berikut: (1) pembinaan dan pengawasan penyelenggaraan pemerintahan daerah kabupaten/kota; (2) koordinasi penyelenggaraan urusan pemerintah (pusat) di daerah provinsi dan kabupaten/kota; dan (3) koordinasi pembinaan dan pengawasan penyelenggaraan tugas pembantuan (medebewind) di daerah provinsi dan kabupaten/kota (UU No. 32 Tahun 2004, Pasal 38, Ayat 1).

Tugas dan wewenang Gubernur cukup kompleks, karena di samping ketiga tugas dan wewenang tersebut di atas, masih ada 16 (enam belas) urusan wajib yang menjadi kewenangan pemerintah daerah provinsi yang merupakan urusan dalam skala provinsi, antara lain penanganan bidang kesehatan, pelayanan bidang ketenanga kerjaan lintas kabupaten/kota, dan pelayanan kependudukan dan catatan sipil (UU No. 32 Tahun 2004, Pasal 13, Ayat 1).

Agar dapat melaksanakan berbagai tugas dan wewenang yang dipikulkan kepadanya di atas dengan sebaik-baiknya, pemerintah daerah provinsi tentunya membutuhkan anggaran yang memadai. Kebutuhan akan anggaran ini menyebabkan hubungan dalam bidang keuangan antara pemerintah (pusat) dan pemerintah daerah tetap sangat diperlukan, seperti dalam hal pengalokasian anggaran perimbangan kepada pemerintahan daerah yang diatur dalam UU No. 33 Tahun 2004 tentang Perimbangan Keuangan Antara Pusat dan Pemerintahan Daerah.

Kebutuhan akan anggaran yang memadai bagi setiap daerah adalah konsekuensi dari wujud pemberian otonomi yang luas kepada daerah, di mana kewenangan (authority) daerah semakin besar. Kewenangan yang dimaksud adalah keleluasaan (diskresi) daerah untuk menyelenggarakan pemerintahan yang mencakup kewenangan semua bidang pemerintahan, kecuali kewenangan dalam bidang politik luar negeri, pertahanan, peradilan, moneter dan fiskal, agama, serta kewenangan bidang lain. Di samping itu, keleluasaan otonomi mencakup 
pula kewenangan yang utuh dan bulat dalam penyelenggaraannya mulai dari perencanaan, pelaksanaan, pengawasan, pengendalian, dan evaluasi.

Dengan otonomi yang luas tersebut, berarti kewenangan (authority) daerah saat ini semakin kompleks, dan salah satu konsekuensinya adalah keharusan pemerintah menyiapkan anggaran yang lebih memadai agar mampu membiayai pelaksanaan berbagai kewenangan yang ada. Dalam konteks ini, faktor keuangan menjadi sangat penting dalam setiap kegiatan pemerintahan, termasuk pelaksanaan berbagai urusan otonomi daerah. Hal ini ditegaskan oleh Suwandi (2009) bahwa implikasi dari penyerahan urusan (wewenang) kepada daerah adalah perlunya daerah mempunyai sumber-sumber pembiayaan untuk membiayai pelaksanaan urusan otonominya tersebut. Dengan kata lain, agar daerah dapat menyelesaikan berbagai tugas yang menjadi wewenangnya, pemerintah daerah membutuhkan anggaran yang memadai (Devas, et al., 2008). Jadi, untuk dapat menyelenggarakan otonomi daerah yang luas, nyata, dan bertanggung jawab, antara lain diperlukan sumber-sumber anggaran (pendanaan).

Khusus untuk anggaran (pendanaan) implementasi kebijakan pelimpahan urusan pemerintahan melalui mekanisme dekonsentrasi (program dan kegiatan dekonsentrasi) di daerah provinsi, atau anggaran untuk tugas-tugas dan wewenang Gubernur sebagaimana dikemukakan sebelumnya, dibebankan kepada Anggaran Pendapatan dan Belanja Negara (APBN), dan anggaran dimaksud disebut dana atau anggaran dekonsentrasi. Konkritnya, kebijakan anggaran dekonsentrasi adalah anggaran yang berasal dari APBN yang dilaksanakan oleh Gubernur sebagai wakil pemerintah (pusat) yang mencakup semua penerimaan dan pengeluaran dalam rangka implementasi dekonsentrasi, tidak termasuk anggaran yang dialokasikan untuk instansi vertikal pusat di daerah (UU No. 33 Tahun 2004, Pasal 1, Angka 26).

Kebijakan anggaran dekonsentrasi tersebut merupakan bagian anggaran kementerian negara/lembaga yang dialokasikan berdasarkan rencana dan anggaran kementerian negara/lembaga. Dengan demikian, kebijakan pendanaan dalam rangka dekonsentrasi dilaksanakan setelah adanya pelimpahan wewenang pemerintah (pusat) melalui kementerian negara/lembaga kepada Gubernur sebagai wakil pemerintah (pusat) di daerah. Kegiatan dekonsentrasi di daerah dilaksanakan oleh Satuan Kerja Perangkat Daerah (SKPD) yang ditetapkan oleh Gubernur.

Fokus dalam kajian ini hanya pelimpahan urusan pemerintahan yang menjadi kewenangan pemerintah (pusat) yang dilaksanakan Kementerian Dalam Negeri. Berbeda dengan anggaran tugas pembantuan (pendanaan dialokasikan untuk program dan kegiatan yang bersifat fisik), pendanaan program dan kegiatan dekonsentrasi di daerah hanya dialokasikan untuk kegiatan yang bersifat non-fisik, seperti kegiatan koordinasi perencanaan, fasilitasi, pelatihan, pembinaan, pengawasan, dan pengendalian.

Oleh karena anggaran dekonsentrasi adalah bagian anggaran kementerian negara/ lembaga yang dialokasikan berdasarkan rencana dan anggaran suatu kementerian negara/lembaga, maka Kementerian-kementerian lain juga ada anggaran dekonsentrasi yang dialokasikan kepada daerah provinsi setelah adanya pelimpahan wewenang dari pemerintah pusat melalui suatu kementerian negara/lembaga. Walaupun demikian, kajian ini difokuskan pada anggaran dekonsentrasi Kementerian Dalam Negeri, sebab anggaran dekonsentrasi yang dialokasikan dari Kementerian tersebut lebih besar dari pada anggaran dekonsentrasi yang dialokasikan dari Kementerian-kementerian lainnya. Hal ini logis karena wewenang pemerintah pusat yang dilimpahkan kepada daerah provinsi melalui Kementerian Dalam Negeri lebih banyak ketimbang wewenang pemerintah pusat yang dilimpahkan kepada daerah provinsi melalui Kementerian-kementerian lainnya. Kewenangan yang dapat dilimpahkan oleh pemerintah pusat kepada Gubernur meliputi sebagaian kewenangan di bidang politik luar negeri, pertahanan keamanan, peradilan, moneter dan fiskal, agama, serta sebagian kewenangan bidang lainnya (perencanaan nasional dan pengendalian pembangunan nasional secara makro, dana perimbangan keuangan, sistem administrasi negara dan lembaga perekonomian negara, pembinaan dan pemberdayaan sumberdaya manusia, pendayagunaan sumberdaya alam dan teknologi tinggi yang strategis, konservasi, dan standarisasi nasional). Di samping itu, Kementerian Dalam Negeri adalah koordinator pembinaan dan pengawasan penyelenggaraan pemerintahan daerah provinsi, sehingga konsekuensinya anggaran dekonsentrasi Kementerian tersebut lebih besar dari anggaran dekonsentrasi Kementerian-kementerian lain.

Selanjutnya, gambaran umum jumlah program, kegiatan, dan anggaran dekonsentrasi Kementerian Dalam Negeri Tahun Anggaran 2011 untuk masing-masing provinsi dapat dilihat pada Tabel 1.

Berdasarkan Tabel 1, anggaran dekonsentrasi Kementerian Dalam Negeri Tahun Anggaran 2011 paling banyak dialokasikan pada Provinsi Papua dan Provinhsi Aceh, yaitu masing-masing Rp. 56,962,673,000 dan Rp. 68,153,216.000. Adapun alokasi anggaran terkecil adalah di Provinsi DKI Jakarta, yaitu hanya sebesar Rp. 320,118,000. Komponen pembina program dekonsentrasi lingkup Kementerian Dalam Negeri TA 2011 adalah Setjen, Ditjen PUM, Ditjen Dukcapil, Ditjen PMD, Ditjen Bina Bangda, dan Badan Diklat Kementerian Dalam Negeri. 
Tabel 1. Jumlah Program, Kegiatan, dan Anggaran Dekonsentrasi Kementerian Dalam Negeri Tahun Anggaran 2011 untuk Masing-Masing Provinsi

\begin{tabular}{|c|c|c|c|c|}
\hline No. & Provinsi & Program & Kegiatan & Anggaran (Rp.) \\
\hline 1 & Aceh & 5 & 12 & $68,153,216.000$ \\
\hline 2 & Sumatera Utara & 6 & 15 & $30,329.479,000$ \\
\hline 3 & Sumatera Barat & 5 & 12 & $11,701,943,000$ \\
\hline 4 & Riau & 4 & 10 & $7,682,195,000$ \\
\hline 5 & Kepulauan Riau & 5 & 10 & $6,195,604,000$ \\
\hline 6 & Jambi & 5 & 11 & $8,638,377,000$ \\
\hline 7 & Sumatera Selatan & 6 & 11 & $12,551,835,000$ \\
\hline 8 & Kep. Bangka Belitung & 5 & 10 & $4,440,021,000$ \\
\hline 9 & Bengkulu & 5 & 12 & $8,855,508,000$ \\
\hline 10 & Lampung & 6 & 10 & $14,026,340,000$ \\
\hline 11 & Banten & 6 & 10 & $11,068,992,000$ \\
\hline 12 & DKI Jakarta & 2 & 2 & $320,118,000$ \\
\hline 13 & Jawa Barat & 5 & 11 & $29,445,613,000$ \\
\hline 14 & Jawa Tengah & 6 & 11 & $28,106,329,000$ \\
\hline 15 & D.I. Yogyakarta & 6 & 11 & $8,353,430,000$ \\
\hline 16 & Jawa Timur & 5 & 12 & $36,097,253,000$ \\
\hline 17 & Bali & 5 & 10 & $6,746,863,000$ \\
\hline 18 & Kalimantan Barat & 5 & 10 & $12,435,196,000$ \\
\hline 19 & Kalimantan Tengah & 4 & 8 & $11,017,396,000$ \\
\hline 20 & Kalimantan Selatan & 5 & 11 & $10,431,372,000$ \\
\hline 21 & KalimantannTimur & 4 & 10 & $12,127,219,000$ \\
\hline 22 & Sulawesi Utara & 5 & 13 & $14,421,229,000$ \\
\hline 23 & Gorontalo & 5 & 10 & $6,958,518,000$ \\
\hline 24 & Sulawesi Tengah & 4 & 12 & $13,040,045,000$ \\
\hline 25 & Sulawesi Barat & 5 & 11 & $7,363,025,000$ \\
\hline 26 & Sulawesi Tenggara & 6 & 12 & $16,147,939,000$ \\
\hline 27 & Sulawesi Selatan & 5 & 13 & $18,319,227,000$ \\
\hline 28 & Nusa Tenggara Barat & 6 & 13 & $12,861,314,000$ \\
\hline 29 & Nusa Tenggara Timur & 5 & 12 & $26,542,561,000$ \\
\hline 30 & Maluku & 5 & 13 & $11,716,222,000$ \\
\hline 31 & Maluku Utara & 5 & 10 & $8,956,616,000$ \\
\hline 32 & Papua & 4 & 12 & $56,962,673,000$ \\
\hline 33 & Papua Barat & 5 & 10 & $24,084,704,000$ \\
\hline
\end{tabular}

Sumber: Lampiran I Permendagri No. 66 Tahun 2010.

Kemudian, berdasarkan hasil pemantauan Biro Perencanaan dan Anggaran Kementerian Dalam Negeri di daerah-daerah provinsi, secara umum kebijakan pelimpahan urusan pemerintahan lingkup Kementerian Dalam Negeri melalui mekanisme dekonsentrasi masih menghadapi barrier/constraint (masalah) di dalam pengimplementasiannya oleh SKPD di daerah. Potret masalah yang dimaksud antara lain masalah perbedaan persepsi para implementor program, egoisme sektoral, pelaporan, serta persoalan sumberdaya (risorsis) pelaksana program.

Masalah perbedaan persepsi dan juga "tarik menarik kepentingan” adalah antara Biro Pemerintahan dan Biro Keuangan dalam pelaksanaan program yang antara lain menyangkut penunjukan bendahara yang harus memiliki sertifikasi kebendaharaan dan umumnya hanya diambil dari Biro Keuangan. Masalah "egoisme sektoral” terutama dikehendaki ada bendahara pada setiap Dinas. Masalah pelaporan muncul karena belum dilaksanakannya pelaporan SAI (Sistem Akuntansi Instansi). Masalah sumberdaya (risorsis) yang dihadapi dalam implementasi kebijakan dekonsentrasi terutama kurangnya SdM (hanya mengandalkan bendahara). Selain itu, masalah lainnya adalah kurangnya sarana dan prasarana pendukung (terutama komputer), kurangnya dana untuk pelaksanaan monitoring dan evaluasi secara berkala, serta tidak tersedianya dana operasional dan belanja honor untuk kuasa anggaran, pembuat komitmen SPM, bendahara, dan staf untuk operator komputer dan pelaporan. (Sumber: Biro Perencanaan dan Anggaran Kemendagri, Desember 2009).

Adanya berbagai permasalahan tesebut di atas dalam implementasi kebijakan pelimpahan urusan pemerintahan lingkup Kementerian Dalam Negeri melalui mekanisme dekonsentrasi di daerah-daerah provinsi selama ini, mendukung rasionalitas "kemengapaan” perlunya dilakukan kajian terhadap implementasi kebijakan dekonsentrasi yang dilaksanakan Kementerian Dalam Negeri. 
Selain itu, hal-hal lainnya yang mendukung pentingnya melakukan kajian ini untuk mendapatkan informasi yang faktual dan bersifat empiris dengan fokus tersebut di atas adalah: (1) Pemantauan yang selalu dilakukan selama ini oleh aparatur Biro Perencanaan Kementerian Dalam Negeri lebih terfokus pada aspek produk atau output (hasil) program-program dekonsentrasi. Padahal, yang paling "krusial" dari sebuah kebijakan pemerintah adalah aspek pengimplementasiannya; (2) Pelaksanaan pemantauan selama ini masih sebatas untuk memenuhi persyaratan administrasi, belum sepenuhnya dapat dimanfaatkan sebagai informasi yang valid dan reliabel untuk pengambilan keputusan manajerial maupun teknis pendayagunaan anggaran program dan kegiatan dekonsentrasi; (3) Kajian terhadap implementasi kebijakan pelimpahan urusan pemerintahan lingkup Kementerian Dalam Negeri melalui mekanisme dekonsentrasi masih sangat terbatas, dan kalaupun ada, kajiannya belum sepenuhnya mengacu pada teori implementasi kebijakan publik dan secara spesifik menggunakan satu konsep implementasi kebijakan; dan (4) Untuk lokasi-lokasi yang dipilih dalam kajian ini, sejauh ini belum pernah ada kajian ilmiah yang meneliti khusus implementasi kebijakan dekonsentrasi lingkup Kementerian Dalam Negeri yang menggunakan ide dan konsep implementasi kebijakan sebagaimana digunakan dalam kajian ini.

Dalam konteks kebijakan publik (public policy), kajian ataupun evaluasi kebijakan publik (pemerintah) paling tidak bermaksud untuk mengetahui 4 (empat) aspek dari sebuah kebijakan, yaitu: (1) proses pembuatan kebijakan, (2) proses implementasi kebijakan, (3) konsekuensi kebijakan, dan (4) efektivitas dampak kebijakan (Wibawa, Purbokusumo, dan Pramusinto, 2004). Dalam konteks evaluasi kebijakan, evaluasi terhadap aspek kedua di atas disebut sebagai evaluasi implementasi kebijakan, sedangkan evaluasi terhadap aspek ketiga dan keempat disebut evaluasi dampak kebijakan.

Keempat aspek kebijakan tersebut di atas dapat mendorong seseorang yang melakukan kajian untuk secara khusus mengkaji content (isi) kebijakan, baik dari dimensi hukum dan terutama dari kelogisannya dalam mencapai tujuan, maupun konteks kebijakan-kebijakan lingkungan yang mempengaruhi seluruh proses kebijakan.

Demikian halnya dengan kebijakan pemerintah mengenai pelimpahan urusan pemerintahan melalui mekanisme dekonsentrasi yang dari segi prosesnya merupakan public policy, juga perlu dikaji melalui kajian ilmiah untuk mengetahui keempat aspek kebijakan yang dikemukakan di atas. Akan tetapi, karena adanya keterbatasan waktu, tenaga, dana, dan agar kajian ini dapat dilakukan secara lebih mendalam (“deepen”), maka kajian ini hanya difokuskan proses implementasi kebijakan dekonsentrasi saja, yang di dalamnya juga mencakup faktor-faktor krusial yang mempengaruhi proses pengimplementasian kebijakan pelimpahan urusan pemerintahan melalui mekanisme dekonsentrasi lingkup Kementerian Dalam Negeri serta hasil dari implementasi kebijakan tersebut.

Berdasarkan fokus di atas, maka pokok permasalahan dalam kajian ini adalah proses implementasi, faktor-faktor yang berpengaruh, serta hasil dari implementasi kebijakan pelimpahan urusan pemerintahan melalui mekanisme dekonsentrasi lingkup Kementerian Dalam Negeri, dengan rumusan masalah sebagai berikut: (1) Bagaimana proses implementasi kebijakan pelimpahan urusan pemerintahan melalui mekanisme dekonsentrasi lingkup Kementerian Dalam Negeri?, (2) Faktorfaktor apa saja yang mempengaruhi implementasi kebijakan pelimpahan urusan pemerintahan melalui mekanisme dekonsentrasi lingkup Kementerian Dalam Negeri?, dan (3) Bagaimana hasil dari implementasi kebijakan pelimpahan urusan pemerintahan melalui mekanisme dekonsentrasi lingkup Kementerian Dalam Negeri?

Sesuai dengan pokok permasalahan kajian di atas, maka tujuan dari kajian ini adalah: (1) Untuk mengetahui proses implementasi kebijakan pelimpahan urusan pemerintahan melalui mekanisme dekonsentrasi lingkup Kementerian Dalam Negeri, (2) Untuk mengidentifikasi faktor-faktor yang mempengaruhi implementasi kebijakan pelimpahan urusan pemerintahan melalui mekanisme dekonsentrasi lingkup Kementerian Dalam Negeri, dan (3) Untuk mengetahui hasil dari implementasi kebijakan pelimpahan urusan pemerintahan melalui mekanisme dekonsentrasi lingkup Kementerian Dalam Negeri.

Acuan teoretik utama yang diperlukan dalam melakukan aktivitas kajian ini adalah konsep pelimpahan urusan pemerintahan melalui mekanisme dekonsentrasi dan konsep implementasi kebijakan publik. Kedua konsep tersebut perlu diuraikan secara "a set interrelation by concept."

Pertama, Kebijakan Pelimpahan Urusan Pemerintahan/Dekonsentrasi. Dalam praktiknya, dalam menyelenggarakan pemerintahaan daerah di Indonesia, pemerintah menggunakan 3 (tiga) asas, yaitu: (1) asas desentralisasi, (2) asas tugas pembantuan, dan (3) asas dekonsentrasi (UU No. 32 Tahun 2004, pasal 20, ayat 2). Konkritnya, pengaturan penyelenggaraan pemerintahan daerah di Indonesia menganut tiga asas (prinsip) yaitu: desentralisasi, tugas pembantuan (medebewind), dan dekonsentrasi. Pelaksanaan asas dekonsentrasi (deconcentration principle) dan kebijakan pendanaannya yang menjadi fokus dalam kajian ini, adalah merupakan pengejawantahan dari teori desentralisasi.

Menurut United Nations (2001), proses desentralisasi melalui delegasi kepada pejabatpejabatnya didaerah pada dasarnya merupakan asas dekonsentrasi. Pada proses atau cara ini, kepada 
pejabat oleh departemen pusat dilimpahkan wewenang dan tanggung jawab bidang tertentu yang bersifat administratif tanpa menerima penyerahan penuh kekuasaan (ini dari segi administration/desentralisasi administrasi, atau asas dekonsentrasi). Jadi, dekonsentrasi adalah suatu delegasi wewenang pelaksanaan yang diberikan kepada pejabat pusat ditingkat lokal (asas dekonsentrasi). Hakikat dari asas dekonsentrasi adalah hanya merupakan pembagian kewenangan dan tanggung jawab administratif antara departemen pusat dengan pejabat-pejabat pusat di lapangan (Rondinelli, 2000).

Di Indonesia dewasa ini, kebijakan dekonsentrasi yang mengacu pada konsep dekonsentrasi sebagaimana dipaparkan sebelumnya, secara normatif diatur dalam UU No. 33 Tahun 2004 tentang Perimbangan Keuangan Antara Pusat dan Pemerintah Daerah, Pasal 87 s/d Pasal 93, UU No. 32 Tahun 2004 tentang Pemerintahan Daerah, Pasal 20, Ayat 2, dan juga PP No. 7 Tahun 2008. Dengan demikian, kajian ini juga mengacu pada UU tersebut dari aspek normatifnya. Pasal-pasal dalam UU tersebut (dan juga penjabaran melalui PP No. 7 Tahun 2008) merupakan landasan konstitusional dan landasan operasional dari kebijakan dekonsentrasi. Adapun landasan filosofis dari kebijakan dekonsentrasi adalah UUD 1945, Pasal 18A, Ayat 2, yang mengamanatkan agar hubungan keuangan, pelayanan umum, dan pemanfaatan sumberdaya alam dan sumberdaya lainnya antara pemerintah (pusat) dan pemerintah daerah diatur dan dilaksanakan secara adil dan selaras. Untuk lingkup Kemendagri, pelaksanaan kebijakan dekonsentrasi Tahun Anggaran 2011 mengacu pada Permendagri No. 66 Tahun 2010.

Dalam penjelasan PP No. 7 Tahun 2008 dinyatakan bahwa Negara Kesatuan Republik Indonesia dalam penyelenggaraan pemerintahannya menganut asas desentralisasi, dekonsentrasi, dan tugas pembantuan. Dekonsentrasi dan tugas pembantuan diselenggarakan karena tidak semua wewenang dan tugas pemerintahan dapat dilakukan dengan menggunakan asas desentralisasi. Disamping itu, sebagai konsekuensi negara kesatuan memang tidak dimungkinkan semua wewenang pemerintah didesentralisasikan dan diotonomkan sekalipun kepada daerah.

Tugas pembantuan bukan hanya kepada daerah provinsi, tetapi juga dialokasikan kepada daerah kabupaten, kota, dan desa. Walaupun kegiatan dekonsentrasi lebih banyak ketimbang kegiatan tugas pembantuan di daerah, namun dari segi pendanaannya, jauh lebih besar dana yang disalurkan untuk kegiatan tugas pembantuan ketimbang dana yang disalurkan untuk kegiatan dekonsentrasi, sebab kegiatan tugas pembantuan bersifat fisik, sedangkan kegiatan dekonsentrasi hanya bersifat non fisik.
Pelaksanaan asas dekonsentrasi diletakkan pada wilayah provinsi dalam kedudukannya sebagai wilayah administrasi untuk melaksanakan kewenangan pemerintahan yang dilimpahkan kepada gubenur sebagai wakil pemerintah di wilayah provinsi. Gubernur sebagai kepala daerah provinsi berfungsi pula selaku wakil Pemerintah di daerah, dalam pengertian untuk menjembatani dan memperpendek rentang kendali pelaksanaan tugas dan fungsi Pemerintah termasuk dalam pembinaan dan pengawasan terhadap penyelenggaraan urusan pemerintahan di daerah kabupaten/kota.

Dasar pertimbangan dan tujuan di selenggarakannya asas dekonsentrasi adalah: (a) terpeliharanya keutuhan Negara Kesatuan Republik Indonesia; (b) terwujudnya pelaksanaan kebijakan nasional dalam mengurangi kesenjangan antar daerah; (c) terwujudnya keserasian hubungan antar susunan pemerintahan dan antarpemerintahan di daerah; (d) teridentifikasinya potensi dan terpeliharanya keanekaragaman sosial budaya daerah; (e) tercapainya efisiensi dan efektifitas penyelanggaraan pemcrintahan, serta pengelolaan pembangunan dan pelayanan terhadap kepentingan umum masyarakat; dan (f) terciptanya komunikasi sosial \& Sosbud. dalam sistem administrasi NKRI.

Untuk lingkup Kemendagri, maksud pelaksanaan kebijakan dekonsentrasi Tahun Anggaran 2011 yang mengacu pada Permendagri No. 66 Tahun 2010 (Pasal 4 ayat 1) adalah untuk mensinergikan hubungan pusat daerah. Adapun arah/tujuannya adalah untuk: (a) meningkatkan kapasitas kelembagaan pemerintah daerah, (b) meningkatkan profesionalisme aparatur pemerintah daerah dalam mendukung reformasi birokrasi, (c) meningkatkan kapasitas kelembagaan pemerintahan desa dan keberdayaan masyarakat perdesaan, (d) meningkatkan keserasian pembangunan antar wilayah, daerah, dan kawasan, dan (e) meningkatkan fungsi-fungsi pelayanan umum pemerintahan (Pasal 4 ayat 2 ).

Adapun program-program dekonsentrasi lingkup Kemendagri adalah: (a) Program dukungan manajemen dan pelaksanaan tugas teknis lainnya Kemendagri, (b) Program pengelolaan desentraslisasi dan Otda, (c) Program penguatan penyelenggaraan pemerintahan umum, (d) Program penataan administrasi kependudukan, (e) Program pendidikan dan pelatihan aparatur Kemendagri, serta (f) Program peningkatan keberdayaan masyarakat perdesaan (Pasal 5).

Penyelenggaraan asas dekonsentrasi tersebut di atas memberikan konsekuensi terhadap pengaturan pendanaan. Semua urusan pemerintahan yang sudah diserahkan menjadi kewenangan pemerintah daerah harus didanai dari APBD, sedangkan urusan pemerintahan yang menjadi kewenangan Pemerintah 
harus didanai dari APBN melalui bagian anggaran kementerian/lembaga. Pengaturan pendanaan kewenangan Pemerintah melalui APBN mencakup pendanaan sebagian urusan pemerintahan yang akan dilimpahkan kepada gubernur berdasarkan asas dekonsentrasi, dan sebagian urusan pemerintahan yang akan ditugaskan kepada daerah provinsi dan kabupaten/kota berdasarkan asas tugas pembantuan. Hal ini sejalan denggn Undang-undang Nomor 33 Tahun 2004 tentang Perimbangan Keuangan antara Pemerintah Pusat dan Pemerintahan Daerah yang menyatakan bahwa perimbangan keuangan antara Pemerintah dan pemerintahan daerah merupakan suatu sistem yang menyeluruh dalam rangka pendanaan atas penyelenggaraan asas desentralisasi, dekonsentrasi, dan tugas pembantuan. Perimbangan keuangan dilaksanakan sejalan dengan pembagian urusan pemerintahan antara Pemerintah dan pemerintahan daerah, yang dalam sistem pengaturannya tidak hanya mencakup aspek pendapatan daerah, tetapi juga aspek pengelolaan dan pertanggungjawaban. Sejalan dengan hal itu, maka penyerahan mewenang pemerintahan, pelimpahan wewenang pemerintahan, dan penugasan dari Pemerintah dalam rangka penyelenggaraan asas desentralisasi, dekonsentrasi, dan tugas pembantuan juga harus diikuti dengan pengaturan pendanaan dan pemanfaatan sumberdaya nasional secara efisien dan efektif.

Anggaran dekonsentrasi pada hakikatnya merupakan bagian anggaran kementerian/ lembaga yang dialokasikan kepada gubernur sebagai wakil Pemerintah di wilayah provinsi sesuai dengan beban dan jenis kewenangan yang dilimpahkan dengan kewajiban melaporkan dan mempertanggung jawabkan kepada yang memberikan pelimpahan.

Pengalokasian anggaran dekonsentrasi tersebut dimaksudkan untuk meningkatkan pencapaian kinerja, efisiensi, dan efektivitas dalam penyelenggaraan pemerintahan, pelayanan publik, dan pembangunan di daerah, serta menciptakan keselarasan dan sinergitas secara nasional antara program dan kegiatan dekonsentrasi yang didanai dari APBN dengan program dan kegiatan desentralisasi yang didanai dari APBD. Selain itu, pengalokasian dana dekonsentrasi dimaksudkan untuk lebih menjamin tersedianya sebagian anggaran kementerian/lembaga bagi pelaksanaan program dan kegiatan yang sudah ditetapkan dalam Renja-KL yang mengacu pada RKP.

Untuk mencapai adanya keselarasan dan sinergitas tersebut di atas, maka dalam penyusunan RKA-KL terlebih dahulu dilakukan proses komunikasi dan perencanaan yang baik antara kementerian/lembaga dengan gubernur yang akan menerima kegiatan pelimpahan wewenang, dan dengan daerah provinsi. Proses komunikasi dan perencanaan tersebut diharapkan dapat tercipta adanya sistem perencanaan dan penganggaran yang terintegrasi dalam kaitannya dengan penyelarasan dan penyesuaian Renja-KL menjadi RKA-KL yang telah dirinci menurut unit organisasi berikut program dan kegiatannya, tarmasuk alokasi sementara untuk pendanaan kegiatan dekonsentrasi.

Prinsip penyelenggaraan dekonsentrasi adalah: (a) Pemerintah menyelenggarakan sebagian urusan yang menjadi kewenangannya di daerah berdasarkan asas dekonsentrasi. Selain berdasarkan asas dekonsentrasi dan tugas pernbantuan, Pemerintah dapat pula menyelenggarakan sendiri sebagian urusan pemerintahan yang mepjadi kewenangannya; (b) Penyelenggaraan dekonsentrasi dilakukan melalui pelimpahan sebagian urusan pemerintahan yang menjadi kewenangan kementerian/ lembaga; dan (c) Kementerian/lembaga menetapkan norma, standar, prosedur, dan kriteria pelaksanaan kegiatan dekonsentrasi. Secara teknis, ruang lingkup kebijakan dekonsentrasi di Indonesia yang diatur dalam PP No. 7 Tahun 2008 mencakup aspek: (a) penyelenggaraan, (b) pengelolaan dana, (c) pertanggungjawaban dan pelaporan, (d) pembinaan dan pengawasan, (e) pemeriksaan, serta (g) sanksi. Penyelenggaraan dekonsentrasi meliputi pelimpahan urusan pemerintahan, tata cara pelimpahan, tata cara penyelenggaraan, dan tata cara penarikan pelimpahan. Pengelolaan dana dekonsentrasi meliputi prinsip pendanaan, perencanaan dan penganggaran, penyaluran dan pelaksanaan, dan pengelolaan barang milik negara hasil pelaksanaan dekonsentrasi. Pertanggungjawaban dan pelaporan dekonsentrasi meliputi penyelenggaraan dekonsentrasi, dan pengelolaan dana dekonsentrasi.

Kedua, Implementasi Kebijakan Publik. Oleh karena fokus kajian ini adalah kajian proses implementasi kebijakan publik (pemerintah), maka konsep yang yang dibahas sebagai acuan teoretik kajian ini adalah batasan dan model implementasi kebijakan yang digunakan. Kebijakan publik (public policy) adalah pola ketergantungan yang kompleks dari pilihan-pilihan kolektif yang saling tergantung, termasuk keputusan-keputusan untuk tidak bertindak, yang dibuat oleh badan atau kantor pemerintah (Dunn, 2004). Sedangkan menurut Dye (2007), kebijakan publik sebagai “... apapun yang dipilih oleh pemerintah untuk dilakukan atau tidak dilakukan.” Dari sudut pandang Dye ini, kebijakan publik itu ditekankan pada pilihan-pilihan apapun yang oleh pemerintah dilakukan atau tidak dilakukan.

Menurut Freeman dan Sharkansky dalam Edward III dan Sharkansky 2004), kebijakan publik adalah apa yang dikatakan dan dilakukan oleh pemerintah, atau yang tidak di lakukannya. Ia adalah tujuan-tujuan atau maksud-maksud dari programprogram pemerintah, bahan-bahan penting dari program-program, dan pelaksanaan niat serta peraturan-peraturan. Adapun kebijakan publik menurut Parker (2004) adalah suatu tujuan tertentu atau serangkaian prinsip atau tindakan yang dilakukan oleh suatu pemerintah pada periode tertentu dalam hubungan dengan suatu objek atau suatu tanggapan terhadap suatu krisis. Menurut Anderson (2000), kebijakan-kebijakan yang 
dikembangkan oleh badan-badan dan pejabat-pejabat pemerintah. Pandangan Dunn, Dye, Freeman dan Sharkansky, Parker, dan Anderson tentang kebijakan publik tersebut di atas prinsipnya sama dan sejalan, yaitu menyamakan kebijakan publik dengan tindakan-tindakan yang dilakukan oleh pemerintah. Para ahli tersebut yang berpendapat demikian cenderung untuk menganggap bahwa semua tindakan yang dilakukan oleh pemerintah dapat disebut sebagai kebijakan publik.

Pandangan lain tentang kebijakan publik adalah para ahli memberikan perhatian khusus pada implementasi kebijakan piblik (public implementation), yaitu memandang kebijakan publik sebagai keputusan-keputusan pemerintah yang mempunyai tujuan-tujuan atau maksud-maksud tertentu. Maksudnya, kebijakan publik adalah serangkaian instruksi dari para pembuat keputusan kepada implementasi kebijakan yang menjelaskan tujuan-tujuan dan cara-cara untuk mencapai tujuan tersebut (Nakamura dan Smallwood dalam Edward III dan Sharkansky, 2004). Di samping itu, kebijakan publik juga dianggap mempunyai akibat-akibat yang dapat diramalkan (predictable), yaitu sebagai suatu hipotesis yang mengandung-kondisi awal yang akibat-akibat implementasinya yang bisa diramalkan (Pressman dan Wildavsky dalam Edward III dan Sharkansky, 2004).

Jadi, jika kita kaji dengan teliti pelbagai definisi yang dikemukakan para analis kebijakan di atas, maka secara garis besar paling tidak terdapat 2 (dua) pandangan, yaitu: (1) kebijakan publik disamakan dengan tindakan-tindakan yang dilakukan oleh pemerintah, di mana semua tindakan yang dilakukan oleh pemerintah dapat disebut sebagai kebijakan publik; dan (2) kebijakan publik yang diaksentualisasikan pada implementasi kebijakan piblik (public implementation), dalam arti serangkaian instruksi dari para pembuat keputusan kepada implementasi kebijakan yang menjelaskan tujuan-tujuan dan cara-cara untuk mencapai tujuan tersebut.

Kebijakan dekonsentrasi dalam pelaksanaan pemerintahan daerah di Indonesia merupakan sebuah kebijakan publik (pemerintah) yang meliputi kedua pengertian di atas. Selain sebagai tindakan dari pemerintah (pusat) yang mengalokasikan dana dekonsentrasi kepada Gubernur sebagai wakil pemerintahan (pusat) di daerah, juga ada serangkaian instruksi dari pemerintah (pusat) melalui kementerian negara/lembaga kepada implementor kebijakan dana dekonstrasi di daerah-daerah provinsi (Gubernur dan para SKPD) yang menjelaskan tujuan-tujuan dan cara-cara untuk mencapai tujuan dari kebijakan dekonsentrasi tersebut. Implementasi kebijakan pelimpahan urusan pemerintahan melalui mekanisme dekonsentrasi lingkup Kemendagri juga sesuai dengan konsep di atas, yaitu pelaksanaan pengendalian aksi-aksi kebijakan dekonsentrasi oleh para implementor di daerah provinsi (Gubernur dan
SKPD) di dalam kurun waktu tertentu, sebagai tindakan yang dilakukan oleh pemerintah (pusat) melalui lembaga Kemendagri, yang dimaksudkan untuk mencapai tujuan sebagaimana dipaparkan di dalam pembahasan kebijakan dekonsentrasi sebelumnya.

Selanjutnya, terdapat berbagai model implementasi kebijakan publik yang dikemukakan para analis kebijakan publik. Model-model yang dimaksud dipaparkan oleh Edward III dalam Edward III dan Sharkansky (2004), seperti Model Kinerja Kebijakan dari Meter dan Horn, Model Konten dan Konteks Kebijakan dari Grindle, Model Top-Down dari Sabatier dan Mazmanian, Model Komunikasi Implementasi Kebijakan dari Goggin, Model Kerjasama dari Weimer dan Vining, Model Terprogram dan Adaptif dari Koenig, dan Model Generasi Ketiga dari Edward III.

Model implementasi kebijakan yang diajukan oleh Edward III disebut sebagai model implementasi kebijakan "Generasi Ketiga", dengan "memformulasikan kembali” berbagai model-model implementasi kebijakan yang telah dikemukakan sebelumnya yang didasarkan pada tataran empiris. Model ini berusaha untuk menjawab beberapa pertanyaan tentang implementasi kebijakan publik, yaitu "prakondisi apa untuk implementasi kebijakan publik yang berhasil?” Artinya, untuk efektivitas dan efisiensi kebijakan, dalam studi implementasi kebijakan dimulai dengan teori dan menanyakan tersebut di atas.

Menurut Edward III, pertanyaan yang penting itu perlu dijawab dengan membicarakan 4 (empat) variabel/faktor krusial yang mempengaruhi (faktor pendukung dan pengahambat) pengimplementasian sebuah program atau kebijakan publik adalah: komunikasi, sumberdaya, disposisi (kecenderungan/kecenderungan/watak atau tingkah laku) pelaksana, dan struktur birokrasi. Keempat atau salah satu dari faktor tersebut dapat diposisikan sebagai faktor pendukung, dan atau dapat pula menjadi faktor penghambat sebuah implementasi kebijakan, sangat tergantung dari kondisi aktual di lapangan.

Setiap implementasi kebijakan atau aksi kebijakan selalu berangkat dari tujuan dan sasaran kebijakan yang telah ditentukan sebelumnya. Untuk mencapai hasil kebijakan atau tujuan yang ingin dicapai, maka dalam aksi kebijakan selalu memerlukan adanya perencanaan, proses pelaksanaan, dan pengendalian. Umpan balik dilakukan jika kebijakan tidak berjalan dengan baik atau tidak sesuai dengan rencana dan tujuan.Model implementasi kebijakan dari Edward III secara skematis dapat dilihat pada Gambar 1 .

Pada dasarnya, model-model implementasi kebijakan publik yang dikemukakan di atas dapat digunakan dalam mengkaji implementasi kebijakan pelimpahan urusan pemerintahan melalui mekanisme dekonsentrasi lingkup Kementerian Dalam Negeri, 


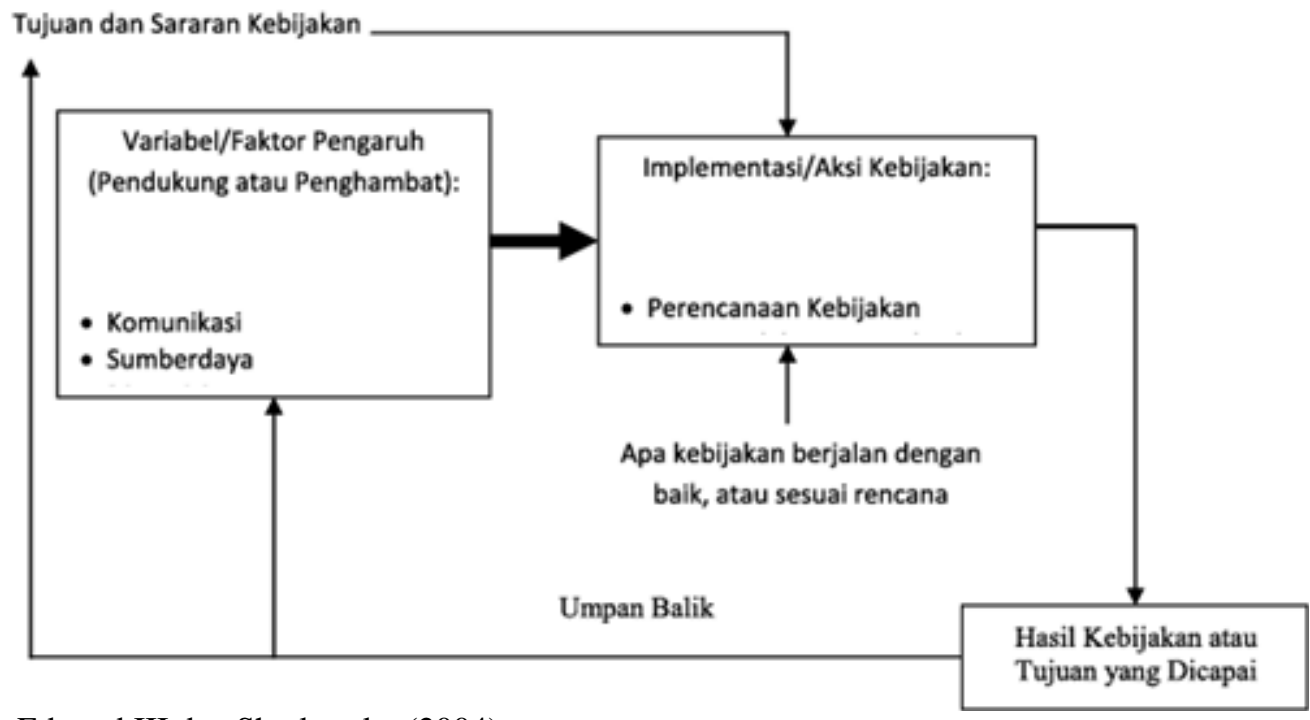

Sumber: Edward III dan Sharkansky (2004).

\section{Gambar 1. Model Implementasi Kebijakan Menurut Edward III}

yang pada pelaksanaan tahun 2011 mengacu pada Permendagri No. 66 Tahun 2010 Tentang Pelimpahan dan Penugasan Urusan Lingkup Kementerian Dalam Negeri Tahun Anggaran 2011. Namun dalam kajian ini, model yang dijadikan acuan (digunakan) adalah Model dari Edward III. Argumennya adalah, di samping karena Model dari Edward III merupakan model implementasi kebijakan “Generasi Ketiga”, juga karena Model dari Edward III itu telah memformulasi kembali berbagai model-model implementasi kebijakan yang yang ada sebelumnya yang didasarkan pada tataran empiris. Apa yang telah dibicarakan dalam model-model implementasi kebijakan sebelumnya sudah tercakup dalam model dari Edward III. Misalnya, faktor kejasama yang dikemukakan dalam Model Weimer dan Vining, faktor perencanaan yang dikemukakan dalam Model Goggin, faktor sumberdaya yang dikemukakan dalam Model Sabatier dan Mazmanian, dan faktor kepatuhan atau sikap yang dikemukakan model Grindle, adalah juga kajian variabel dan aksi kebijakan dalam Model Edward III.

Selanjutnya, penjelasan implementasi/aksi kebijakan dan variabel dalam Model Edward III di atas dijelaskan berikut ini.

(1) Implementasi/Aksi Kebijakan: (a) Perencanaan Kebijakan, yaitu pemilihan sekumpulan kegiatan dan pemutusan selanjutnya apa yang akan dilakukan, kapan, bagaimana, dan oleh siapa. Suatu rencana program kebijakan hanya dapat baik jika dalam setiap kegiatan-kegiatan itu diambil langkah-langkah yang tepat (Handoko, 2006), (b) Proses Pelaksanaan Kebijakan, yaitu apa yang terjadi setelah peraturan perundang-undangan diterapkan yang memberikan otoritas pada suatu program, manfaat atau suatu bentuk keluaran yang jelas (tangible). Proses ini disebut sebagai policy delivery system, yaitu sebagai penghubung yang memungkinkan tujuan-tujuan kebijakan publik menjadi hasil dari aktivitas pemerintah. Dengan kata lain, dalam proses pelaksanaan kebijakan bertujuan untuk mengatasi masalah yang hendak diatasi, tujuan yang hendak dicapai, serta cara-cara untuk memecahkannya (Mardiasmo, 2002), dan (c) Pengendalian Kebijakan, yaitu upaya sistematik untuk menetapkan standar pelaksanaan dengan tujuan-tujuan perencanaan, merancang sistem informasi timbal balik, termasuk membandingkan kegiatan nyata dengan standar yang telah ditetapkan, menentukan dan mengukur penyimpangan-penyimpangan, serta mengambil tindakan-tindakan koreksi yang diperlukan untuk menjamin bahwa semua sumberdaya dalam pelaksanaan kebijakan digunakan dengan cara paling efektif dan efisien dalam pencapaian tujuan-tujuan kebijakan (Robert J. Mockler dalam Handoko, 2006).

(2) Variabel Pengaruh: (a) Komunikasi, yaitu kejelasan standar dan sasaran tidak menjadi implementasi kebijakan yang efektif jika tidak dibarengi dengan adanya komunikasi antarorganisasi dan aktivitas pengukuhan. Semua implementor kebijakan harus memahami apa yang diidealkan oleh kebijakan yang dimplementasikannya itu menjadi tanggung jawab mereka. Hanya saja komunikasi adalah proses yang rumit, yang sangat potensial untuk terjadi penyimpangan. Ini menyangkut persoalan kewenangan dan kepemimpinan. Organisasi atasan (superior) mestinya mampu mengkoordinasikan organisasi bawahan atau implementor kebijakan untuk memiliki idealita sebagaimana yang dikehendaki oleh sebuah 
kebijakan (Wibawa, dkk., 2004), (b) Sumberdaya (Risorsis), yaitu setiap pelaksanaan kebijakan menuntut tersedianya sumberdaya, baik yang berupa dana, maupun insentif lain sebagai pendukung implementasi kebijakan, seperti manusia pelaksana (human) dan peralatan (non human). Kinerja kebijakan akan rendah apabila dana yang dibutuhkan tidak tersedia oleh pemerintah secara memadai (Wibawa, dkk., 2004), (c) Disposisi (kecenderungan/kecenderungan/ watak atau tingkah laku), yaitu sikap pelaksana terhadap kebijakan yang mereka implementasikan, untuk pada akhirnya menentukan seberapa tinggi tingkat kinerja kebijakannya. Kognisi, netralitas, dan objektivitas para individu sangat mempengaruhi bentuk respon mereka terhadap semua faktor tersebut (Wibawa, dkk., 2004), dan (d) Struktur Birokrasi, yaitu implementasi kebijakan juga harus didukung oleh karakteristik birokrasi pelaksana yang baik, dalam arti potensial dan aktual/nyata. Dalam kontek kebijakan publik, Ripley (2005) menyatakan bahwa struktur birokrasi pelaksana (bureaucratic structure), yang meliputi karakteristik atau cara pelaksanaan program, norma atau aturan main dalam pelaksanaan kebijakan, dan pola hubungan antar pelaksana kebijakan - yang potensial maupun aktual sangat berpengaruh terhadap keberhasilan implementasi kebijakan.

(3) Hasil Kebijakan, yaitu hasil sebuah kebijakan terutama dilihat dari target yang dicapai dan terjadinya peningkatan dari apa yang menjadi tujuan sebuah kebijakan (Edward III dan Sharkansky, 2004).

Adapun alur pikir dalam kajian ini didasarkan pada uraian-uraian di atas dan digambarkan pada Gambar 2.

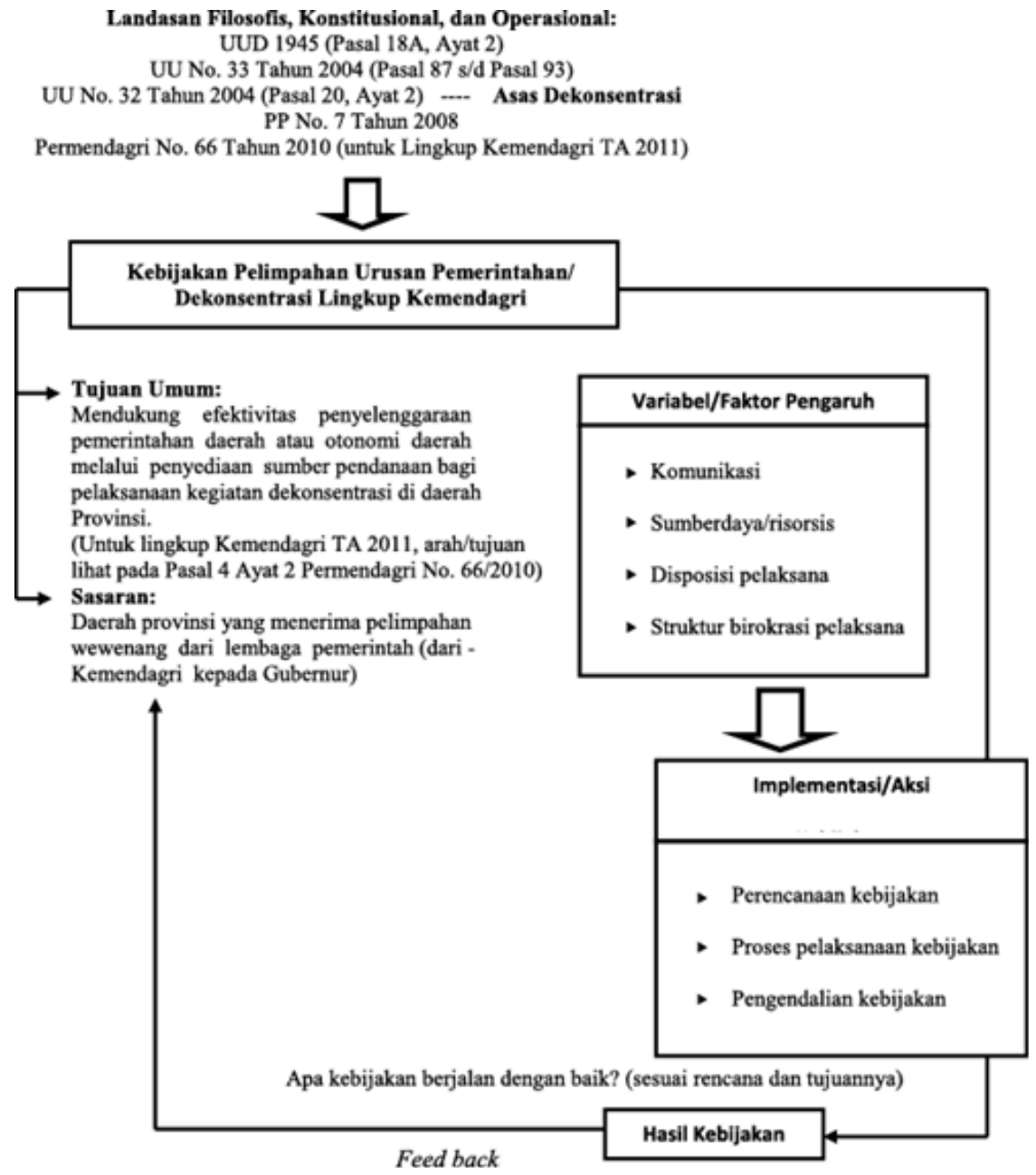

Gambar 2. Alur Pikir Kajian Implementasi Kebijakan Pelimpahan Urusan Pemerintahan/Dekonsentrasi Lingkup Kementerian Dalam Negeri 


\section{METODE}

Pelaksanaan penelitian dalam kajian ini mengikuti prosedur sebagaimana lazimnya digunakan dalam sebuah penelitian. Pendekatan yang digunakan adalah naturalistik. Dilihat dari tingkat eksplanasinya, kajian ini termasuk jenis penelitian deskriptif yang bersifat eksploratif. Penelitian deskriptif merupakan penelitian non hipotesis sehingga dalam langkah penelitiannya tidak perlu merumuskan hipotesis. Penelitian deskriptif yang bersifat eksploratif bertujuan untuk menggambarkan keadaan atau status fenomena (Suharsimi, 2006). Dalam hal ini surveyor hanya ingin mengetahui dan mengidentifikasi hal-hal yang berkaitan dengan proses implementasi kebijakan pelimpahan urusan pemerintahan melalui mekanisme dekonsentrasi lingkup Kementerian Dalam Negeri Tahun Anggaran 2011.

Oleh karena keterbatasan anggaran kajian ini, maka hanya dipilih salah satu daerah penerima dana dekonsentrasi yang besar, yaitu Provinsi Jawa Barat yang menerima dana sebesar Rp. 29,445,613,000 pada TA 2011. Kajian ini dilaksanakan selama 3 (tiga) bulan, yaitu dari pertengahan September s/d pertengahan Desember 2012.

Beritik tolak dari deskripsi kebijakan pelimpahan urusan pemerintahan (melalui mekanisme dekonsentrasi) lingkup Kementerian Dalam Negeri dan sintesa kerangka pemikiran yang telah dipaparkan pada Pendahuluan sebelumnya, maka ditetapkan kriteria-kriteria standar objektif yang digunakan dalam mengkaji dan menilai implementasi kebijakan tersebut. Kriteria-kriteria standar objektif dibangun atas dasar pemikiran ideal sebuah kebijakan dekonsentrasi. Kriteria standar objektif ini akan dijadikan sebagai patokan standar untuk mengukur dan menilai baik tidaknya implementasi kebijakan dekonsentrasi. Adapun kriteria-kriteria standar objketif yang dijadikan sebagai acuan kajian ini dapat dilihat pada Lampiran Tabel 2.

Pengumpulan data dalam kajian ini mengunakan teknik: (1) dokumentasi, dan (2) wawancara. Ada 2 (dua) jenis data yang dikumpulkan, yaitu: (1) data yang berbentuk kuantitatif (angka-angka dan persentase), dan (2) data yang berbentuk kualitatif (deskripsi).
Sumber data dalam penelitian ini adalah dari arsip rekap./laporan-laporan dalam bentuk tabel serta dari aparat Biro Pem./Asisten Pem./Bappeda Provinsi dan aparat SKPD pelaksana kegiatan program dekonsentrasi Tahun Anggaran 2011.

Sesuai dengan kedua teknik pengumpulan data yang digunakan di atas, maka instrumen (alat) kajian atau alat pengumpulan data yang dipakai dalam dalam ini adalah: (1) ceklis dokumen, dan (2) pedoman wawancara terbuka.

Informan dalam kajian ini adalah aparat Biro Pemerintahan/Bappeda Provinsi serta aparat SKPD pelaksana kegiatan program dekonsentrasi Tahun Anggaran 2011 (masing-masing 2 SKPD per provinsi).

Analisis data dalam kajian ini menggunakan teknik deskriptif. Setelah data terkumpul, maka lalu diklasifikasikan menjadi 2 (dua) kelompok data, yaitu data kualitatif dan data kuantitatif. Terhadap data yang bersifat kualitatif (yang dihimpun melalui wawancara), yaitu yang digambarkan dengan katakata atau kalimat, dipisah-pisahkan menurut kategori untuk memperoleh kesimpulan. Adapun data yang bersifat kuantitatif (yang dihimpun melalui dokumentasi), yang berwujud angka-angka, diproses dengan cara ditabulasikan, dihitung, dijumlahlah, atau dipersentasekan, dan kemudian dideskripsikan.

Selanjutnya, kriteria-kriteria kajian yang telah ditetapkan sebelumnya merupakan ukuran atau patokan standar objektif kajian implementasi kebijakan dekonsentrasi. Hasil kajian atau intensitas objektif dari lapangan dibandingkan dengan standar objektif yang telah ditetapkan. Teknik pengambilan keputusan aktualitas standar objektif pada setiap aspek dan sub aspek kajian dilakukan dengan cara melakukan pengukuran pada setiap fokus kajian yang dirangkum dalam matrik yang diadaptasi dalam case-order effect matrix (Sabarguna, 2005). Model matrik ini memiliki karakteristik yang khas, yaitu menampilkan adanya efek-efek perbandingan antara standar objektif berupa kriteria-kriteria normatif dan empirik yang telah ditetapkan sebelumnya dengan intensitas objektif, yaitu berupa hasil rekaman nyata di lapangan (data). Selanjutnya, perbandingan tersebut akan menghasilkan efek simpulan (konklusi), yaitu berupa aktualitas standar objektif keputusan

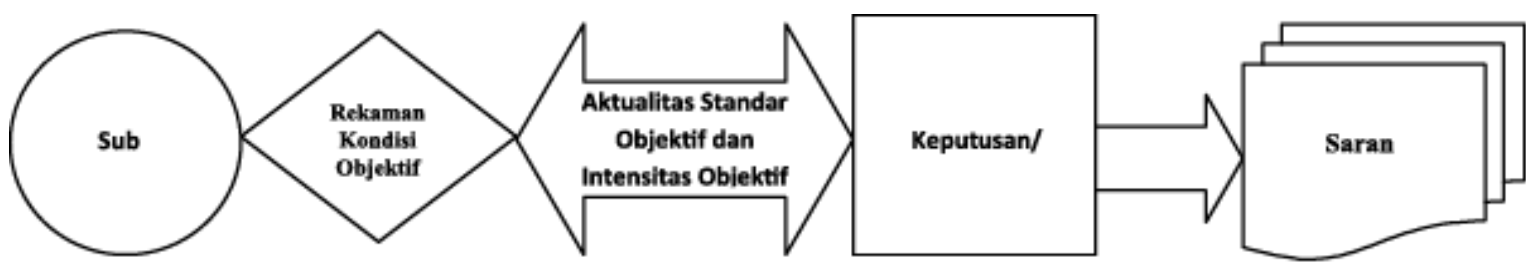

Gambar3. Teknik Analisis Data 
kasus yang diambil/dikaji. Aktualitas standar objektif yang dikaji ditetapkan dengan menggunakan 3 (tiga) pilihan kategori, yaitu: tinggi (high), moderat (moderate), dan rendah (low) (Issac dan Michael, 2000).

\section{HASIL DAN PEMBAHASAN}

Provinsi Jawa Barat memiliki luas sebesar 3.584.644,92 hektar, dengan kondisi topografis beragam. Secara administratif, pada tahun 2008 Provinsi Jawa Barat terdiri dari 26kabupaten/kota, yang terbagi dalam 17 kabupaten dan 9 kota, yaitu: Kabupaten Bogor, Sukabumi, Cianjur, Bandung, BandungBarat, Garut, Tasikmalaya, Ciamis, Kuningan Cirebon, Majalengka, Sumedang, Indramayu, Subang, Purwakarta, Karawang, Bekasi, serta Kota Bogor, Sukabumi ,Bandung, Cirebon, Bekasi, Depok, Cimahi, Tasikmalaya dan Banjar. Jumlah penduduk Provinsi Jawa Barat, hingga akhir tahun 2007 mencapai 41.483 .729 jiwa, dengan laju pertumbuhan penduduk 1,83\%.

Progam, kegiatan, sub kegiatan, anggaran, serta komponen pembina pelaksanaan kebijakan dekonsentrasi lingkup Kemendagri Tahun Anggaran 2011 di Provinsi Jawa Barat dapat dilihat pada Lampiran Tabel 2.

Secara umum, penyerapan keuangan adalah target $100 \%$ dan realisasi adalah $76,61 \%$, sedangkan penyerapan fisik adalah target $100 \%$ dan realisasi adalah 83,62\%. Untuk Program Penataan Administrasi Kependudukan, Kegiatan Dukungan Manajemen dan Pelaksanaan Tugas Teknis Lainnya Ditjen Dukcapil, Sub Kegiatan Sosialisasi UU No. 52/2009 tentang Perkembangan Kependudukan dan Pembangunan Keluarga, Penerbitan NIK di 168 Kab./Kota \& Monev Imple. SIAK Kab./Kota, dengan anggaran Rp. 1.048.100.000, realiasasinya $98,50 \%$.

Adapun untuk Program Pemberdayaan Masyarakat dan Pemerintahan Desa, Kegiatan Peningkatan Kemandirian Masyarakat Perdesaan, dan Sub Kegiatan PNPM Mandiri Perdesaan, dengan anggaran Rp. 25.409.000, realisasinya adalah 89,93\%. Kendala umum yang dihadapi adalah: (1) pelaksanaan kegiatan PNPM Mandiri Perdesaan regular masih berproses dan baru sampai pada tahap penetapan prioritas usulan (perlu proses tahapan kegiatan PNPM Mandiri Perdesaan terintegrasi regular terus dilanjutkan sesuai PTO), (2) pelaksanaan PNPM Mandiri Perdesaan diintegrasi belum ada pelatihan untuk para pelaku program (perlu mengikuti peltihan nasional dalam rangka persiapan PNPM Mandiri Perdesaan Integrasi), dan (3) target anggaran dari cost sharing APBD kabupaten belum sesuai dengan aturan yang tersurat dalam SE Ditjen PMD Kemendagri (perlu pemerintah kabupaten dapat memenuhi dana koshering yang seharusnya, sesuai dengan NPUB yang telah dibuat).
Dokumen-dokumen yang ditemukan di lapangan terkait dengan pelaksanaan kebijakan dekonsentrasi lingkup Kemendagri TA 2011 di Provinsi Jawa Barat adalah:

1. Laporan manajerial oleh Kepala SKPD pelaksana dekonsentrasi T.A. 2011.

2. Laporan akuntabilitas oleh KPA sebagai penanggung jawab atas pengelolaan anggaran barang/jasa yang dibiayai dari DIPA dekonsentrasi T.A. 2011.

3. Inventarisasi pencatatan seluruh barang hasil pelaksanaan dekonsentrasi T.A. 2011.

4. SK penetapan SKPD T.A. 2011.

5. SK penetapan pejabat perbendaharaan pelaksana kegiatan dekonsentrasi T.A. 2011 (KPA, PPK, PP-SPM, dan Bendahara Pengeluaran).

6. SK penetapan PPTK T.A. 2011 (jika KPA menunjuk PPTK).

7. Laporan hasil pelaksanaan setiap kegiatan program dekonsentrasi T.A. 2011.

Proses Implementasi Kebijakan Pelimpahan

Urusan Pemerintahan (Melalui Mekanisme Dekonsentrasi) Lingkup Kementerian Dalam Negeri Tahun Anggaran 2011 di Provinsi Jawa Barat, antara lain: Pertama, Perencanaan Kebijakan Dekonsentrasi. Proses perencanaan dan penganggaraan senantiasa memperhatikan aspek pembagian urusan pemerintahan (sesuai dengan PP 38/2007 tentang Pembagian Urusan Pemerintah antara Pemerintah, Pemerintah Daerah Provinsi dan Pemerintah Daerah Kabupaten/Kota). Tidak semua urusan dekonsentrasi yang telah direncanakan dan diserahkan kepada daerah adalah benar-benar merupakan urusan dekonsentrasi/bukan urusan desentralisasi (masih ada kegiatan dekonsentrasi kemendagri yang malaksanakan urusan desenralisasi, contoh kegiatan lembaga keuangan mikro pedesaan, pasar Desa, TK PK). Urusan dekonsentrasi yang telah direncanakan dan diserahkan kepada daerah sesuai dengan tujuan kebijakan dekonsentrasi dan juga peran Gubernur cukup “nyambung.”

Perencanaan kebijakan dekonsentrasi sesuai dengan kondisi riil/kebutuhan riil lokasi/daerah provinsi, karena daerah akan melakukan sinkronisasi dalam menyusun rencana kegiatan yang dibiayai dari APBD supaya tidak terjadi tumpang tindih pembiayaan untuk kegiatan yang sudah dibiayai dari APBN. Perencanaan dan penetapan alokasi dan lokasi dekonsentrasi cukup transparan dan akuntabel. Setiap perencanaan kebijakan dekonsentrasi didasarkan pada kinerja kebijakan dekonsentrasi yang lalu (sebagai salah satu indikator penilaian diberikannya dekonsentrasi berikutnya). Perencanaan kebijakan dekonsentrasi sesuai dengan perencanaan pembangunan nasional. Kegiatankegiatan kebijakan dekonsentrasi yang direncanakan sinkron dengan rencana kegiatan pembangunan daerah.

Program dan kegiatan-kegiatan kebijakan dekonsentrasi sesuai dengan kewenangan dan 
kemampuan keuangan negara. Program dan kegiatan-kegiatan kebijakan dekonsentrasi yang direncanakan mengakomodasi aspek efisiensi dan efektivitas. Perencanaan kegiatan dekonsentrasi lingkup Kemendagri sudah optimal (khususnya terkait dengan hal-hal teknis seperti penyusunan juklat dan juknis, sinergi kegiatan pusat dan daerah, dan kapasitas aparatur pelaksana kebijakan dekonsentrasi), di mana dalam penyusunan Juklak dan Juknis, sinergi kegiatan pusat daerah,termasuk optimalisasi aparatur pelaksana dekonsentrasi.

Perencanaan kegiatan-kegiatan kebijakan dekonsentrasi yang dilakukan oleh SKPD pelaksana sepenuhnya didasarkan pada ketentuan yang telah ditetapkan. Selain itu, perencanaan program dan kegiatan-kegiatan kebijakan dekonsentrasi sesuai dengan Tupoksi SKPD pelaksana.

Kedua, Proses Pelaksanaan Kebijakan Dekonsentrasi. Kemendagri sepenuhnya menyelenggarakan dekonsentrasi yang sesuai dengan amanat PP No. 7 Tahun 2008. Belum ada penjabaran lebih lanjut atas PP No. 38 Tahun 2007 tentang pembagian urusan, khususnya urusan yang sifatnya concurrent (urusan bersama). Tidak perlu Kemendagri melaksanakan kegiatan-kegiatan kebijakan dekonsentrasi yang begitu banyak, yang diperlukan kegiatan dekon yang sifatnya substansial/urgent untuk Kemendagri. Belum dilaksanakan amanat pengalihan urusan yang bukan urusan dekonsentrasi ke DAK telah dilaksanakan pemerintah.

Kriteria penetapan lokasi dan alokasi dana dekonsentrasi cukup jelas. Bappeda Provinsi mampu mencakup semua SKPD pelaksana kebijakan dekonsentrasi. Dalam kaitannya untuk pencairan/penyerapan dana dekonsentrasi, penyelesaian revisi DIPA/RKA-KL di tingkat Pusat mengalami keterlambatan (terkait dengan revisi terjadi keterlambatan di dalam penyerapan hal ini disebabkan, proses Revisi DIPA memerluka waktu yang panjang). Tidak ada kendala di dalam pelaksanaan koordinasi program dan kegiatan dekonsentrasi (Mendagri, Gubernur, Pejabat Eselon I Pembina, Pejabat Eselon II, dan Para Kepala SKPD. Semua kegiatan pembinaan (pemberian pedoman, fasilitasi, pelatihan, serta pemantauan dan evaluasi) kebijakan dekonsentrasi dilaksanakan dan juga berjalan dengan baik. Pola pembinaan dalam pelaksanaan kebijakan dekonsentrasi yang dilakukan selama ini cukup efektif (dilakukan koordinasi setahu 2 kali). Tidak ada kesulitan yang dihadapi dalam melakukan pembinaan pelaksanaan kebijakan dekonsentrasi.

Seluruh barang hasil pelaksanaan kebijakan dekonsentrasi memang seharusnya dicatat oleh SKPD-SKPD pelaksana sebagai aset persediaan, namun pelaksanaan Dekonsentrasi tidak menghasilkan asset persediaan. Demikian halnya, SKPD pelaksana kebijakan kegiatan pusat seharusnya melakukan pencatatan barang hasil pelaksanaan kegiatan dekonsentrasi pada buku manual Satker saja, namun tidak ada pencatatan barang kegiatan Dekonsentrasi, karena kegiatan Dekonsentrasi tidak menghasilkan barang. Demikian halnya, seluruh SKPD pelaksana kebijakan kegiatan pusat menatausahakan barang sebagai BMD dan sudah melalui proses hibah dari Kemendagri kepada daerah, namun tidak ada pencatatan barang kegiatan Dekonsentrasi, karena kegiatan Dekonsentrasi tidak menghasilkan barang. Semua barang yang dibeli atau diperoleh dari dana dekonsentrasi benar-benar digunakan untuk keperluan pelaksanaan kegiatan dekonsentrasi, sepanjang barang untuk menunjang kegiatan utama. Perlu tertib pengelolaan aset tetap dekonsentrasi, namun tidak ada pencatatan barang kegiatan Dekonsentrasi, karena kegiatan Dekonsentrasi tidak menghasilkan barang/tidak ada pengelolaan aset tetap.

Pertimbangan dalam penetapan pejabat perbendaharaan pelaksana kegiatan-kegiatan kebijakan dekonsentrasi (KPA, PPK, PP-SPM, dan Bendahara Pengeluaran) benar-benar telah sesuai dengan ketentuan peraturan perundang-undangan. Penetapan pejabat perbendaharaan pelaksana kegiatan kebijakan dekonsentrasi (KPA, PPK, PPSPM, dan Bendahara Pengeluaran) tidak terlambat dan juga tidak berganti-ganti.

KPA tidak menetapkan PPTK. Format baku pembukuan kas cukup disosialisasikan. Update software terbaru cepat diinformasikan pada SKPD pelaksana kebijakan dekonsentrasi. Kegiatan-kegiatan kebijakan dekonsentrasi yang dilaksanakan oleh SKPD tidak mirip-mirip dan juga tidak overlapping. Barang-barang yang dibeli dari dana dekonsentrasi adalah ATK dan barang habis pakai. Tengang penatausahaan barang hasil pelaksanaan kebijakan dekonsentrasi, tidak ada, terkait dengan barang persediaan habis pakai.

Ketiga, Pengendalian Kebijakan Dekonsentrasi. Seluruh SKPD pelaksana melakukan pelaporan dan pertanggung jawaban dana dekonsentrasi, tetapi waktu penyampaiannya tidak tepat waktu. Penyampaian laporan tahunan pelaksanaan kebijakan dekonsentrasi yang disampaikan Gubernur kepada Mendagri tepat waktu sebagaimana yang telah ditentukan. Materi yang dimuat dalam laporan manajerial kegiatan dekonsentrasi sesuai dengan ketentuan yang telah ditetapkan (sudah sesuai dengan PP 39/2006 tentang tata cara pengendali dan Evaluasi Pelaksanaan Rencana Pembangunan, baik substansi/isi/materi). Materi yang dimuat dalam laporan akuntabilitas kegiatan dekonsentrasi sesuai dengan ketentuan yang telah ditetapkan.

Kualitas laporan manajerial kegiatan dekonsentrasi sudah baik, tetapi masih ada yang belum melaporkan permasalahan dan kendala. Kualitas laporan akuntabilitas kegiatan dekonsentrasi sudah baik. Hasil laporan kegiatan dekonsentrasi telah dimanfaatkan secara optimal, 
untuk dihimpun dan dijadikan bahan laporan Gubernur kepada Pemerintah Pusat. Pengawasan pelaksanaan kebijakan dekonsentrasi yang dilakukan selama ini belum efektif, karena alokasi anggaran terbatas/tidak mencukupi.

Tidak ada kendala ayang dihadapi dalam melakukan pengawasan pelaksanaan kebijakan dekonsentrasi (dalam hal moner kepada SKPD pelaksanaan Dekonsentrasi lingkup Kemendagri). Pemeriksaan pelaksanaan kebijakan dekonsentrasi yang dilakukan selama ini efektif (semua kegiatan Dekonsentrasi yang dilaksanakan oleh SKPD sudah berjalan sesuai dengan waktu yang ditentukan). Tidak ada masalah yang dihadapi dalam melakukan pemeriksaan pelaksanaan kebijakan dekonsentrasi (semua sesuai dengan waktu yang ditentukan). Tidak ada SKPD pelaksana dekonsentrasi yang secara sengaja dan/atau lalai dalam menyampaikan laporan kegiatan kebijakan dekonsentrasi (semua SKPD pelaksanaan dekonsentrasi Kemendagri telah melaporkan/menyampaikan laporan kepada Bappeda, namun masih ada yang melaporkan/menyampaikan laporan tidak tepat waktu).

Tidak ada kendala yang dihadapi dalam pelaksanaan penyusunan laporan manajerial kegiatan dekonsentrasi. Demikian halnya, tidak ada kendala yang dihadapi dalam pelaksanaan penyusunan laporan akuntabilitas kegiatan dekonsentrasi. Selain itu, tidak ada juga kendalakendala yang dihadapi dalam pelaksanaan penyusunan/ penyampaian laporan keuangan kegiatan dekonsentrasi.

Penyusunan dan penyampaian laporan manajerial kegiatan dekonsentrasi dari SKPD setiap triwulan dan berakhirnya tahun anggaran kegiatan tepat waktu sebagaimana telah ditentukan (selambatlambatnya laporan akhir tahun pada bulan maret tahun berikutnya). Penyusunan dan penyampaian laporan akuntabilitas kegiatan dekonsentrasi dari SKPD setiap triwulan dan berakhirnya tahun anggaran kegiatan tepat waktu sebagaimana telah ditentukan (selambat-lambatnya laporan akhir tahun pada bulan maret tahun berikutnya). Laporan-laporan yang harus dibuat dalam pelaksanaan kebijakan dekonsentrasi tidak overload, karena ditangani/dikerjakan oleh pelaksana teknis yang menangani kegaiatn dekon. Sudah ada format laporan hasil kegiatan dekonsentrasi yang baku (SKPD bukan menggunakan format laporan sendirisendiri/ tidak sama), yaitu laporan kinerja dan akuntabilitas sesuai dengan Peraturan Perundangundangan.

Faktor-faktor yang Mempengaruhi Implementasi Kebijakan Pelimpahan Urusan Pemerintahan (Melalui Mekanisme Dekonsentrasi) Lingkup Kementerian Dalam Negeri Tahun Anggaran 2011 di Provinsi Jawa Barat. Pertama, Faktor Komunikasi Para Pelaksana Kebijakan Dekonsentrasi. Di dalam pelaksanaan komunikasi pusat dan daerah dalam rangka implementasi kebijakan dekonsentrasi tidak terlalu topdown, karena sebelum pelaksanaan teknis dilakukan komunikasi pusat dengan daerah. Tidak ada penyimpangan dalam pelaksanaan komunikasi (melalui koordinasi) para pelaksana kebijakan dekonsentrasi.

Proses komunikasi (melalui koordinasi) di antara pelaksana kebijakan dekonsentrasi dalam SKPD pelaksana tidak rumit. Mekanisme dan tata cara yang digunakan dalam pelaksanaan komunikasi (melalui koordinasi) di antara pelaksana kebijakan dekonsentrasi dalam SKPD pelaksana cukup tepat/efektif.

Kedua, Faktor Sumberdaya Pelaksanaan Kebijakan Dekonsentrasi. KPA cukup mampu menyusun DIPA dan petunjuk operasional kegiatankegiatan kebijakan dekonsentrasi. Pengawas pelaksanaan kebijakan dekonsentrasi cukup mampu menjalankan tugasnya. Para pejabat perbendaharaan pelaksana kegiatan dekonsentrasi cukup mampu menjalankan tugasnya (KPA, PPK, PP-SPM, dan Bendahara Pengeluaran). Tidak ada kendala yang dihadapi dalam penyaluran dana dekonsentrasi (sesuai dengan mekanisme penyerahan DIPA). Pencairan/penyerapan dana dekonsentrasi terlambat, karena terkait dengan revisi DIPA. Penggunaan jenis belanja bantuan sosial pada pelaksanaan dana dekonsentrasi tidak tepat, karena bantuan sosial lebih tepat di kegiatan Tugas Pembantuan. SdM pelaksana kebijakan dekonsentrasi (SKPD-SKPD pelaksana) cukup terampil menjalankan tugasnya. Latar belakang dan tingkat pendidikan yang dimiliki para pelaksana kegiatan kebijakan dekonsentrasi dari SKPD-SKPD pelaksana cukup mendukung kelancaran implementasi kebijakan tersebut (kebanyakan berlatar belakang pendidikan D3, S1, dan S2). Pelaksana kegiatan kebijakan dekonsentrasi dari SKPD-SKPD pelaksana memiliki mental/moral yang baik (jujur, dll.)

Pemeriksa pelaksanaan kebijakan dekonsentrasi cukup mampu menjalankan tugasnya. Penyusun laporan manajerial kegiatan dekonsentrasi memiliki kemampuan (pengetahuan dan keterampilan) penyusunan laporan tersebut yang cukup memadai. Penyusun laporan akuntabilitas kegiatan dekonsentrasi memiliki kemampuan (pengetahuan dan keterampilan) penyusunan laporan tersebut yang cukup memadai. Dana yang tersedia cukup memadai untuk pelaksanaan kegiatan kebijakan dekonsentrasi. Tersedia biaya pemeliharaan pada DIPA untuk aset dekonsentrasi. Perlu kegiatankegiatan kebijakandekonsentrasi yang kecil-kecil dananya digabung saja (penggabungan kegiatan Dekon yang kecil-kecil oleh satu DIPA). Tingkat realisasi penyerapan dana dekonsentrasi cukup tinggi, yaitu sebesar $81,14 \%$ atau sebesar $81,14 \% \mathrm{X}$ 55,532,621,000 : $100=\operatorname{Rp}$ 45.059.168.679. Tidak 
ada masalah yang dihadapi di dalam pencairan/penyerapan anggaran dekonsentrasi. Fasilitas atau peralatan yang dibutuhkan dalam pelaksanaan kebijakan dekonsentrasi cukup memadai. Kualitas fasilitas atau peralatan untuk pelaksanaan kebijakan dekonsentrasi yang ada cukup baik/layak pakai/ memenuhi kapasitas atau kebutuhan.

Ketiga, Faktor Disposisi Para Pelaksana Kebijakan Dekonsentrasi. Para pelaksana kebijakan dekonsentrasi dari SKPD-SKPD pelaksana mematuhi seluruh ketentuan pelaksanaan dekonsentrasi yang telah ditetapkan. Para pelaksana kebijakan dekonsentrasi dari SKPD-SKPD pelaksana senantiasa konsisten dan konsekuen menjalankan seluruh tugasnya.

Seluruh pelaksana kebijakan dekonsentrasi dalam SKPD pelaksana ini memiliki komitmen yang tinggi dalam melaksanakan tugasnya. Demikian pula, seluruh pelaksana kebijakan dekonsentrasi dalam SKPD inbi memiliki tanggung jawab yang tinggi dalam menjalankan tugasnya.

Keempat, Faktor Struktur Birokrasi Pelaksanaan Kebijakan Dekonsentrasi. Kemendagri telah menyusun dan menetapkan norma, standar, prosedur, dan akuntabilitas pelaksanaan kebijakan dekonsentrasi. Para pelaksanaan program dan kegiatan-kegiatan dalam kebijakan dekonsentrasi yang ditetapkan Pusat cukup efesien dan efektif pelaksanaannya di daerah, contoh kongkretnya, dalam rangka koordinasi dengan SKPD penerimaan Dekonsentrasi Kemendagri. Hubungan antara komponen pembina dengan pelaksana kebijakan dekonsentrasi di daerah dan antar pelaksana kebijakan dekonsentrasi di daerah berlangsung dengan baik.

Norma (ketentuan perundangan dan pedoman pelaksanaan kebijakan dekonsentrasi) yang dibuat oleh pemerintah dan Kemendagri cukup jelas. Seluruh pelaksana kegiatan dekonsentrasi dalam SKPD pelaksana ini mudah memahami dan melaksanakan norma dekonsentrasi yang ditetapkan pemerintah/Kemendagri. Juklat dan juknis pelaksanaan dekonsentrasi dari pusat tidak mengalami keterlambatan (juklak dan juknis diterima tepat waktu).

Hasil Implementasi Kebijakan Pelimpahan Urusan Pemerintahan (Melalui Mekanisme Dekonsentrasi) Lingkup Kementerian Dalam Negeri Tahun Anggaran 2011 di Provinsi Jawa Barat. Secara umum hasil yang dicapai dari pelaksanaan kegiatan-kegiatan program dekonsentrasi telah sesuai dengan tujuan-tujuan dari pelaksanaan kebijakan dekonsentrasi. Keluaran dari pelaksanaan kegiatan program dekonsentrasi mencapai target sebagaimana yang telah ditetapkan sebelumnya. Terealisasinya seluruh target yang ditetapkan dalam DIPA bahkan target melebihi, karena kegiatan PNPM-mandiri pedesaan ada anggaran pendamping/penunjang di APBD dan dana partisipasi masyarakat.
Pengukuran Aktualitas Standar Objektif Implementasi Kebijakan Pelimpahan Urusan Pemerintahan (Melalui Mekanisme Dekonsentrasi) Lingkup Kementerian Dalam Negeri Tahun Anggaran 2011 Di Provinsi Jawa Barat. Tabel/matrik pengukuran aktualitas standar objektif implementasi kebijakan pelimpahan urusan pemerintahan (melalui mekanisme dekonsentrasi) lingkup Kemendagri Tahun Anggaran 2011 di Provinsi Jawa Barat dapat dilihat pada Tabel 2.

Berdasarkan matrik/tabel pada Lampiran Tabel 2, secara umum aktualitas standar objektif implementasi kebijakan pelimpahan urusan pemerintahan (melalui mekanisme dekonsentrasi) lingkup Kemendagri Tahun Anggaran 2011 di Provinsi Jawa Barat masih berada pada kategori moderat/sedang/cukup baik (baik dari segi perencanaan, proses pelaksanaan, pengendalian, hasil kebijakan, maupun dari segi tingkat permasalahan yang ada). Kendati terdapat beberapa item (butir) dari intensitas objektif yang berada pada aktualitas standar objektif dengan kategori tinggi/baik (sesuai/sangat sesuai dengan standar objektif yang telah ditetapkan), namun tidak sedikit pula item (butir) dari intensitas objektif yang berada aktualitas standar objektif dengan kategori moderat (kurang sesuai dengan standar objektif yang telah ditetapkan), termasuk masih adanya beberapa permasalahan/kendala yang dihadapi dalam pelaksanaan kebijakan tersebut. Kondisi kategori seperti itu juga cukup dipengaruhi paling tidak 4 (empat) faktor, yaitu komunikasi, sumberdaya, disposisi, dan struktur birokrasi pelaksana kebijakan pelimpahan urusan pemerintahan (melalui mekanisme dekonsentrasi) lingkup Kemendagri.

Hal-hal yang masih kurang sesuai dengan kriteria-kriteria standar objektif kajian implementasi kebijakan dekonsentrasi yang telah ditetapkan adalah:

1. Belum ada penjabaran lebih lanjut atas PP No. 38 Tahun 2007 tentang pembagian urusan, khususnya urusan yang sifatnya concurrent (urusan bersama).

2. Belum dilaksanakan amanat pengalihan urusan yang bukan urusan dekonsentrasi ke DAK telah dilaksanakan pemerintah.

3. Dalam kaitannya untuk pencairan/penyerapan dana dekonsentrasi, penyelesaian revisi DIPA/RKA-KL di tingkat Pusat mengalami keterlambatan (terkait dengan revisi terjadi keterlambatan di dalam penyerapan hal ini disebabkan, proses Revisi DIPA memerluka waktu yang panjang).

4. KPA tidak menetapkan PPTK.

5. Kualitas laporan manajerial kegiatan dekonsentrasi sudah baik, tetapi masih ada yang belum melaporkan permasalahan dan kendala.

6. Pengawasan pelaksanaan kebijakan dekonsentrasi yang dilakukan selama ini belum efektif, karena alokasi anggaran terbatas/tidak mencukupi. 
Tabel 2. Program, Kegiatan, Sub Kegiatan, Anggaran, dan Komponen Pembina Pelaksanaan Kebijakan Dekonsentrasi Kementerian Dalam Negeri Tahun Anggaran 2011 Di Provinsi Jawa Barat.

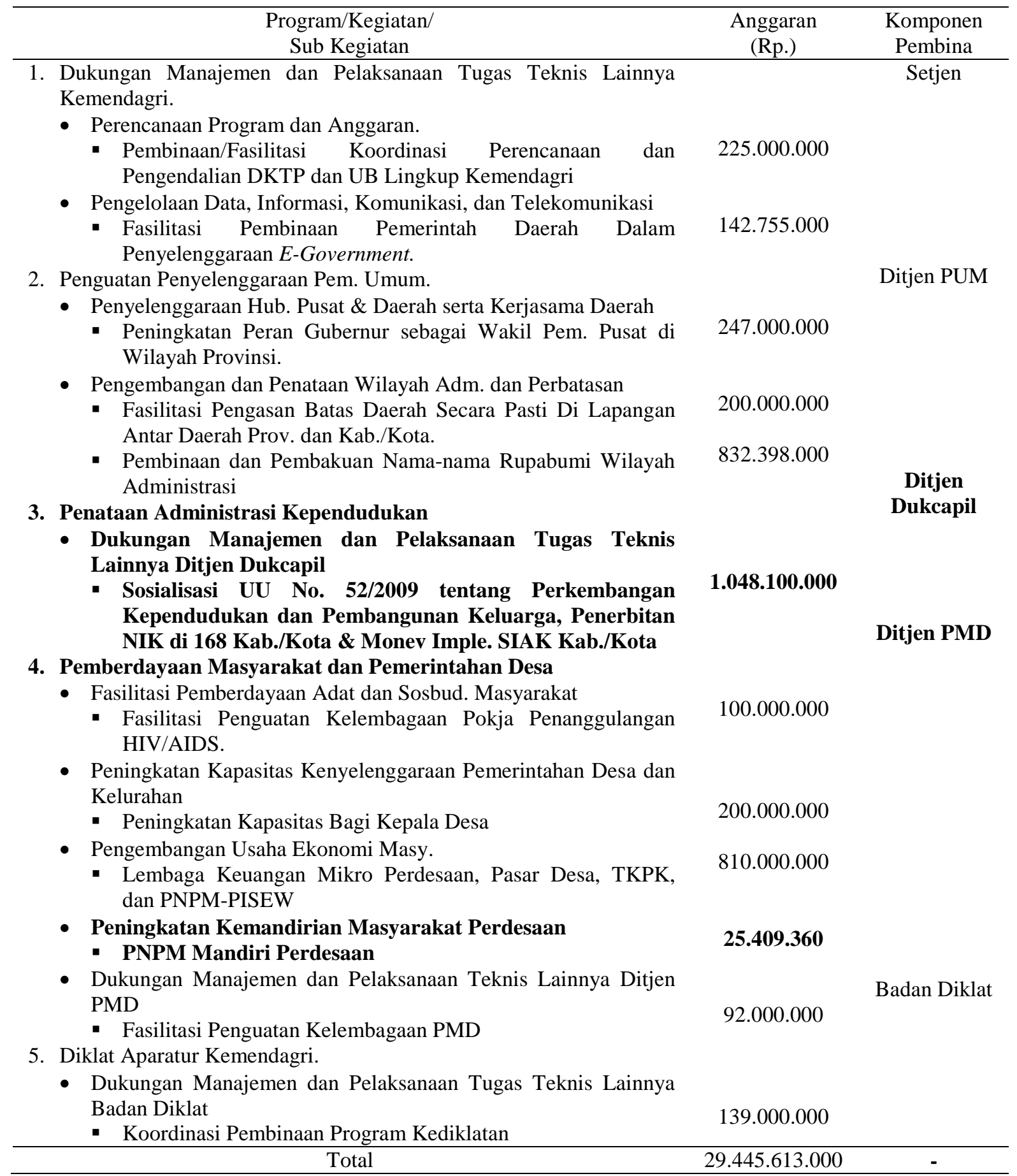

Sumber: Bappeda Provinsi Jawa Barat, 2011.

7. Pelaksanaan kegiatan PNPM Mandiri Perdesaan regular masih berproses dan baru sampai pada tahap penetapan prioritas usulan.

8. Pelaksanaan program PNPM Mandiri Perdesaan diintegrasi belum ada pelatihan untuk para pelaku program.

9. Target anggaran dari cost sharing APBD kabupaten belum sesuai dengan aturan yang tersurat dalam SE Ditjen PMD Kemendagri.
10. Pencairan/penyerapan dana dekonsentrasi terlambat, karena terkait dengan revisi DIPA.

11. Penggunaan jenis belanja bantuan sosial pada pelaksanaan dana dekonsentrasi tidak tepat, karena bantuan sosial lebih tepat di kegiatan Tugas Pembantuan. 


\section{KESIMPULAN}

Secara umum, hasil dari implementasi kebijakan dekonsentrasi di Provinsi Jawa Barat relatif sesuai dengan tujuan-tujuan dari pelaksanaan kebijakan dekonsentrasi. Demikian halnya keluaran dari pelaksanaan kegiatan program dekonsentrasi mencapai target sebagaimana yang telah ditetapkan sebelumnya. Walaupun demikian, masih terdapat berbagai kekurangan di dalam proses pelaksanaannya. Oleh karena itu, perlu penguatan (reposisi atau optimalisasi) peran gubernur dalam hubungan pusat-daerah, peningkatan sinergitas pusat dan daerah dalam perencanaan dan penganggaran kegiatan dekonsentrasi. peningkatan kapasitas kelembagaan/SKPD pelaksana dekonsentrasi, serta pengembangan kapasitas SdM aparatur pemerintah daerah. Selain itu, Kemendagri sebaiknya tidak perlu lagi melaksanakan kegiatan-kegiatan kebijakan dekonsentrasi yang begitu banyak untuk menghindari pemborosan anggaran, yang diperlukan adalah kegiatan-kegiatan dekonsentrasi yang sifatnya substansial/ urgen untuk Kemendagri. Kegiatankegiatan kebijakan dekonsentrasi lingkup Kemendagri yang kecil-kecil dananya perlu digabung saja (penggabungan kegiatan-kegiatan dekonsentrasi yang kecil-kecil oleh satu DIPA).

\section{Daftar Pustaka}

Anderson, James E. 2000. Public Policy Making. New York: Praeger Publishers.

Departemen Dalam Negeri. 2001. Peraturan Pemerintah Nomor 39 Tahun 2001 Tentang Penyelenggaraan Dekonsentrasi.

2008. Peraturan Pemerintah Nomor 7 Tahun 2008 Tentang Dekonsentrasi dan Tugas Pembantuan.

Perencanaan Depdagri Tentang Hasil Monitoring Pelaksanaan Dana Dekonsentrasi dari Depdagri di Daerah-daerah Provinsi Tahun 2003-2005.

--------. 2007. Dekonsentrasi dan Tugas Pembantuan Lingkup Depdagri TA 2007.

2007. Pedoman Umum
Pengelolaan Dekonsentrasi dan Tugas Pembantuan Lingkup Depdagri TA 2007.

Devas, Nick, et al. 2008. Financing Local Government in Indonesia. New York: Oxford University Press.

Dunn, William N. 2004. Public Policy Analysis : An Introduction. London: Prentice-Hall International, Inc.

Dye, Thomas R. 2007. Understanding Public Policy. New Jersey: Prentice Hall.

Edwards III, George C. dan Ira Sharkansky (Ed.). 2004. Mengimplementasikan Kebijakan Publik. Terjemahan Samodra Wibawa, dkk. Yogyakarta: Gadjah Mada University Press.

Ermaya Suradinata. 2008. Manajemen Pemerintahan dan Otonomi Daerah. Bandung: Ramadan.
Grindle, Meriles S. (ed.). 2000. Politic and Policy Implementation in The Third World. New Jersey: Princeton University Press.

Handoko. 2006. Manajemen. Yogyakarta: BP-FE UGM.

Iglesias, Gabriel U. 2007. Regionalization and Regional Develompment in the Philippines. Manila: UPCPA.

Islamy, M. Irfan. 2008. Prinsip-prinsip Perumusan Kebijakan Negara. Jakarta: PT Bina Aksara.

Issac, Stephen dan William B. Michael. 2000. Handbook in Research and Evaluation. San Diego California: Edits Publisher.

Jaques, Elliot. 2007. Merubah Faktor-faktor Kultur Organisasi, diterjemahkan oleh Iman Bukhari. Jakarta: LAN-RI.

Lee, Thayer. 2001. Administrasi Komunikasi, diterjemahkan oleh Penerbit Bina Aksara. Jakarta: Bina Aksara.

Lipson, Lislie. 2001. The Great Issues of Politic : An Introduction to Political Science. New Jersey: Prentice-Hall, Inc.

Mardiasmo. 2002. Otonomi dan Manajemen Keuangan Daerah. Yogyakarta: ANDI.

Meter, Donald S. dan Van Horn. 2005. “The Policy Implementation Process : A Conceptual Framework", dalam Administration and Society. Beverly Hills: Sage Publication.

Mulgan, R. 2007. "The Process of Public of Accountability”, dalam Australian Journal of Public Administration. 56 (1), 25-36.

Parker, R.S. 2004. ”Policy and Administration” dalam In Public Policy and Administration in Australia : A Reader. Sydney: John Wiley and Sons.

Pressman, J.L. dan A. Wildavsky. 2000. Implementation. Berkeley: University of California.

Republik Indonesia. 1999. Perubahan Kedua UUD Negara Republik Indonesia Tahun 1945. 2004. Undang-undang No. 32 Tahun 2004 Tentang Pemerintahan Daerah.

2004. Undang-undang No. 33 Tahun 2004 Tentang Perimbangan Keuangan Antara Pusat dan Pemerintahan Daerah.

Ripley, Randall B. 2005. Political Analysis in Political Sciences. Chicago: Nelson Hall, Inc.

Riwu Kaho, Josef. 2005. Prospek Otonomi Daerah Di Negara Republik Indonesia : Identifikasi Beberapa Faktor yang Mempengaruhi Penyelenggaraannya. Jakarta: PT RajaGrafindo Persada.

Rondinelli, Dennis A. dan Cheeme G. Shabbir. 2000. Decentralization and Development, Policy, Implementation in Developing. California: Sage Publications, Inc., Baverly Hills.

Sabarguna, Boy S. 2005. Analisis Data pada Penelitian Kualitatif. Jakarta: UI Press.

Sabatier, Paul dan Daniel Mazmanian. 2000. “Top Down and Bottom Up Approach to Implementation Research.” Journal of Public Administration. No. XI (2), 23-32.

Suharsimi Arikunto. 2006. Prosedur Penelitian : Suatu Pendekatan Praktek. Jakarta: Rineka Cipta. 
Surianingrat, Bayu. 2000. Desentralisasi dan Dekonsentrasi : Pemerintahan di Indonesia Suatu Analisa. Jakarta : Dewaruci Press.

Sutarto. 2004. Dasar-dasar Organisasi. Yogyakarta: Gadjah Mada University Press.

Suwandi, I made. 2009. "Perimbangan Keuangan Antara Pemerintah Pusat dan Daerah di Indonesia.” Dewan, 08, hal. 44-49.

United Nations. 2001. A Handbook of Public Administration : Current Concept and Practice with Special Reference to Developing Countries. New York: UN.

Wahab, Solichin. 2001. Pengantar Analisis Kebijakan Negara. Jakarta: CV Rineka Cipta.

Wibawa, Samodra, Yuyun Purbokusumo, dan Agus Pramusinto. 2004. Evaluasi Kebijakan Publik. Jakarta: Rajawali Press.

Yasin, Fauzi Alvi. 2009. Perkembangan Akuntansi Pemerintah Daerah. Jakarta:

IAI. 